\title{
La resistencia cultural a las dictaduras del Cono Sur. Un estudio comparado de la solidaridad desde Francia y Suecia con Chile y Argentina a partir de la gráfica política (1973-1990) ${ }^{1}$
}

\author{
Fernando Camacho Padilla \\ Moira Cristiá ${ }^{3}$
}

Resumen: La instauración de dictaduras militares en el Cono Sur a lo largo de las décadas de los años sesenta y setenta conmocionó profundamente a los sectores progresistas de los países europeos. Si en años anteriores ya había emergido un significativo movimiento de solidaridad y apoyo a los gobiernos revolucionarios latinoamericanos, tras los golpes de Estado los comités reorientaron su labor a la acogida de exiliados y a la denuncia de las violaciones a los derechos humanos. Además de ejercer presión política, se organizaron numerosas actividades culturales, en las que participaron tanto artistas e intelectuales locales como latinoamericanos, gran parte de los cuales habían llegado como exiliados. Con el fin de reflexionar sobre el efecto, la significación y legado de esta experiencia, en este artículo se analiza en perspectiva comparada la dimensión cultural de la solidaridad en Suecia y Francia con Chile y Argentina, focalizando especialmente en la gráfica política. El trabajo concluye que

\footnotetext{
1 Artículo desarrollado en el marco de los siguientes proyectos: "Nuevos actores en las relaciones internacionales contemporáneas durante los procesos de descolonización de África, Asia y América Latina (1810-1990). Redes políticas, alianzas y cooperación Sur-Sur", financiado por la Comunidad de Madrid a través del Convenio Plurianual con la Universidad Autónoma de Madrid, V PRICIT, SI1/PJI/2019-00493; e "Imágenes dialécticas. Cruces de arte, cultura, comunicación y política entra la última dictadura y el presente", financiado por la Universidad de Buenos Aires, UBACyT $\mathrm{n}^{\circ}$ 20020170100299BA. Los autores agradecen la colaboración de Pierre Bercis, Liliana Andreone, Thierry Couderc (de la Biblioteca de l'INSEE Alain Desrosières), Pepe Viñoles, Rosemarie Andersson, Margareta Björling, Göran Sallnäs y Enrique Ganuza.

${ }^{2}$ Doctor en Historia por la Universidad Autónoma de Madrid (UAM) y la Pontificia Universidad Católica de Chile (PUC). Actualmente es profesor del Departamento de Historia Contemporánea de la UAM. Sus principales publicaciones tratan sobre las relaciones entre Chile y Suecia, así como las comisiones de la verdad en el Cono Sur. En los últimos años, sus investigaciones se han centrado en la historia de Irán, así como en las relaciones contemporáneas de América Latina con Medio Oriente, especialmente durante el siglo XX. ORCID: 0000-0002-4734-9061.E-mail: fernando.camacho@uam.es.

${ }^{3}$ Doctora en Historia y Civilizaciones por l'École des Hautes Études en Sciences Sociales de París. Es investigadora del Consejo Nacional de Investigaciones Científicas y Técnicas (CONICET) en el Instituto de Investigaciones Gino Germani (Universidad de Buenos Aires) donde integra el Grupo de Estudios sobre Arte, Cultura y Política en la Argentina Reciente. Es miembro de la Red de Conceptualismos del Sur y del comité editorial de Nuevo Mundo Mundos Nuevos. Es autora de artículos en revistas y compilaciones, así como de los libros Imaginaire péroniste. Esthétique d'un discours politique (19661976) y AIDA. Una historia de solidaridad artística transnacional (1979-1985). ORCID: 0000-00015829-4126. E-mail: moicristia@gmail.com.
} 
mientras los exiliados conosureños intentaban debilitar a los regímenes dictatoriales desde el espacio público transnacional convocando un apoyo externo, sus aliados europeos representaban esas demandas a partir de experiencias que apelaran a la sensibilidad local. Es decir, o bien se evocaban otros ejemplos de crímenes de trascendencia internacional, o bien se las vinculaba a las propias experiencias traumáticas del pasado reciente europeo.

Palabras clave: exilio; solidaridad transnacional; derechos humanos; Cono Sur; Francia, Suecia

\title{
Cultural resistance to the dictatorships of the Southern Cone. A comparative study of solidarity with Chile and Argentine in France and Sweden from the political graphics (1973-1990)
}

\begin{abstract}
The establishment of military dictatorships in the Southern Cone in the 1960s and 1970s deeply shocked the progressive sectors of European countries. Before the military coups, a significant solidarity movement had already emerged to support the Latin American revolutionary governments. After the breakdown of democracy and the systematization of repressive practices, the committees reoriented their work to welcoming exiles and denouncing human rights violations. In addition to exerting political pressure, numerous activities and cultural events were organized, in which both local and Latin American artists and writers participated, most of whom arrived as exiles. In order to reflect on the effect, significance and legacy of this experience, this article analyzes as a case study the cultural dimension of solidarity in Sweden and France with Chile and Argentina in comparative perspective, focusing on the political graphics. The study concludes that while the exiles from the Southern Cone tried to weaken the dictatorial regimes from the transnational public space by summoning external support, their European allies represented these demands appealing to local sensibilities. In other words, they chose either to evoke other sensitive examples of crimes of international concern or to reference their own traumatic experiences of their recent past.
\end{abstract}

Keywords: exile; transnational solidarity; human rights; Southern Cone; France; Sweden

Artigo recebido em: 02/03/2021

Artigo aprovado para publicação em: 27/04/2021

\section{Introducción}

La instauración de dictaduras militares en el Cono Sur a lo largo de la década de los años setenta conmocionó profundamente a los sectores progresistas de los países 
europeos por la violencia aplicada contra los opositores políticos, así como por la represión y censura a artistas e intelectuales. Tanto la cercanía cultural y lingüística de esos países con Europa Meridional como la rapidez con la que llegaba la información, permitió a las sociedades del Viejo Mundo seguir de cerca el desarrollo de aquellos acontecimientos. La secuencia temporal de golpes de Estado en América Latina en general, y en el Cono Sur en particular, que tuvieron lugar durante las décadas de los años sesenta y setenta, generalmente comparten entre sí grandes similitudes causales e ideológicas, lo cual no hacía difícil su comprensión por la ciudadanía europea.

Cabe destacar que tanto los intelectuales como estudiantes y sectores progresistas de ese continente seguían en detalle el devenir de los acontecimientos políticos en la región. América Latina fue, desde el siglo XIX, un territorio en el que todo parecía posible, desde enriquecerse hasta poner en práctica las utopías socialistas. En la segunda mitad del siglo XX, la profundización de las desigualdades e injusticias sociales y la expansión de ideas revolucionarias lo convirtieron en un caldo de cultivo en el que los procesos emancipadores se tornaron, para muchos, un proceso legítimo y, además, necesario.

A medida que se fue avanzando en la década de los sesenta, las posturas moderadas, también conocidas como reformistas, aplicadas por gobiernos de centro tales como el Partido Demócrata Cristiano de Chile, fueron perdiendo fuerza. La retórica política experimentó, en líneas generales, una profunda radicalización y polarización. El opositor, tanto desde la izquierda como de la derecha, pasó a ser visto como un enemigo al que combatir. No fue hasta los años ochenta cuando las tendencias moderadas recuperaron fuerza. Esto se debió, por un lado, a que los sectores más radicalizados de la izquierda fueron diezmados a causa de la represión, y aquellos que lograron sobrevivir se vieron obligados a esconder sus planteamientos. Por otro lado, la mayor parte de los organismos de derechos humanos surgidos en la segunda mitad de los años setenta $\mathrm{y}$, especialmente durante los ochenta, condenaban la violencia. Asimismo, algunos sectores tradicionalistas se distanciaron de los regímenes 
autoritarios por sus acciones represivas ${ }^{4}$. En este proceso, el centro político, a pesar de sus múltiples matices, se amplió como lugar de encuentro y diálogo que favoreció el restablecimiento de las democracias en el Cono Sur, con líderes o gobiernos que mayoritariamente tomaban distancia de los polos ideológicos. Con el final de la Guerra Fría y el derrumbe del socialismo real en 1989, además, la vía revolucionaria perdió vigencia en los debates entre las principales fuerzas políticas.

A pesar de la lejanía geográfica, Europa Occidental veía los procesos políticos de Latinoamérica con gran interés. Antes de producirse los golpes de Estado de la década de los años setenta, ya existía un significativo movimiento de solidaridad ${ }^{5}$ con las causas o los gobiernos revolucionarios, como ocurrió a raíz de la llegada al poder de Fidel Castro en Cuba desde 1959, o una década más tarde, el triunfo de Salvador Allende en Chile en 1970. Gran parte de los activistas europeos eran partícipes también de otras causas internacionales, como la guerra de Vietnam o el apoyo a los procesos de descolonización que se estaban desarrollando en varios puntos de África y Asia.

En esta "época", que en términos de Gilman (2003) transcurre desde comienzos de la década de los años sesenta a finales de los ochenta, se emplearon distintas estrategias culturales para visibilizar y fomentar el compromiso con los pueblos del otro lado del Atlántico. De este modo, con la interrupción de la democracia en los países del Cono Sur y la sistematización de prácticas represivas, los comités de apoyo a las luchas revolucionarias latinoamericanas reorientaron su labor a la acogida de exiliados, a la denuncia de las violaciones a los derechos humanos y a la promoción de la recuperación del Estado de derecho. Para ello, además de ejercer presión política por medio de manifestaciones, peticiones y publicando boletines y manifiestos, se organizaron numerosas actividades y veladas culturales, en la que participaron tanto artistas e intelectuales locales como latinoamericanos, gran parte de los cuales se habían visto

\footnotetext{
${ }^{4}$ El viraje ideológico de los sectores que defendieron o incluso participaron en los golpes de Estado en América Latina es un tema escasamente investigado. Si bien cada país tiene sus propias características, la mayoría de quienes inicialmente habían apoyado la toma del poder por parte de las fuerzas armadas más tarde sufrieron un desencanto. Para el caso chileno, véase el trabajo de Casals (2018). La teoría de los dos demonios del prólogo escrito por Ernesto Sábado en el Informe Nunca Más (1984) ejemplifica claramente la posición favorable que tuvo en un inicio un sector de la sociedad argentina frente al golpe, así como su posterior distanciamiento.

${ }^{5}$ El significado de solidaridad en los planos éticos, religiosos y políticos ha sido investigado en detalle por Stjernø (2005).
} 
forzados a salir de su país por cuestiones políticas. A pesar de las diferencias ideológicas, dentro del espectro de izquierda existía un objetivo común: la recuperación de la democracia y el fin de las violaciones a los derechos humanos. Este último asunto se convirtió, por primera vez, en una temática dominante en la producción artística latinoamericana, abarcando numerosas esferas, tales como la cinematografía, el teatro, el documental, el muralismo, el arte pictórico, la cartelería, el arte callejero, la música o la fotografía, entre muchos otros, las cuales han sido en buena parte investigados por la academia. $^{6}$

Asimismo, una abundante historiografía ha abordado la acción de los exiliados latinoamericanos durante las décadas de los años setenta y ochenta, centrada generalmente en un país expulsor o receptor. ${ }^{7}$ A diferencia del exilio latinoamericano en el siglo XIX y principios del XX restringido a las élites políticas, en el período que nos concierne este fenómeno se tornó masivo. En consecuencia, la estructura del exilio devino más compleja. Según Sznadjer y Roniger (2013) a los tres factores dinámicos clásicos (el país expulsor, el país receptor y los exiliados) se sumó un cuarto factor: la esfera pública transnacional o dominio transnacional. Esta nueva dimensión funcionó “operando contra el supuesto monopolio del Estado-Nación sobre las esferas públicas nacionales y la política, al potenciar a los exiliados en términos de su influencia y posicionamiento transnacional y la resonancia de sus voces en la arena global" (SZNADJER \& RONIGER, 2013, p. 181-183).

\footnotetext{
${ }^{6}$ A modo general, entre otros, véase: Jelin \& Longoni (2005); Amigo Cerisola \& Gutiérrez Castañeda (2012); Errázuriz \& Leiva Quijada (2012); Villota Ruiz (2015); Stites Mor \& Suescun Pozas (2018); Richard (2007), Norambuena (2008). Sobre cinematografía, véase los trabajos de: Amaral de Aguiar; Crepaldi Carvalho; Ramos Monteiro; Adamatti; Villaçalos (2019); Amado (2009). Respecto al cine documental, véase: Campo \& Doraro (2007); Stites Mor (2012); Museo de la Memoria y los Derechos Humanos (2015). Sobre arte, véase: Carvajal, Varas \& Vindel (2019); Cristiá (2021); Museo de la Memoria y los Derechos Humanos (2014). Sobre fotografía: Leiva Quijada (2008); Camacho Padilla \& Ramírez Palacio (2018); Castillo Troncoso (2017); Richard (2015). Sobre cartelería: Vico \& Osses (2009); Vico (2013); Cristi \& Manzi (2016); Castillo Espinoza (2010). Sobre afiches en el exilio: Stobinski, Gittis \& Rückert (1981).

${ }^{7}$ Con una perspectiva histórica del exilio, véase, a modo de ejemplo, los trabajos de Horvitz y Peñaloza (2017); Camacho Padilla (2011); del Pozo (2006); Franco (2008); Yankelevich (2010); Jensen (2009); Prognon (2011); Sáenz Carrete (1995); Dutrénit Bielous (2006); Morales Muñoz (2018); y Rojas Mira (2019). Desde una perspectiva artística, véase: Aguirre Argomedo \& Chamorro Martínez (2008); y Camacho Padilla (2009).
} 
El presente artículo se centra en las características de la dimensión cultural del exilio de los perseguidos del Cono Sur en Europa Occidental, y más concretamente en Suecia y Francia, los cuales fueron dos de sus principales destinos. Si bien ciertos rasgos son singulares en cada país, notamos una dinámica que trasciende esas fronteras. Esto se debe a varios factores como la presencia de exiliados de esa región en el continente europeo y a su acción articulada en la causa que defendían. Así, músicos como Quilapayún, Inti Illimani o el Cuarteto Cedrón realizaban giras de recitales en las actividades de solidaridad de distintos países, las cuales, junto con sus publicaciones y correspondencias, funcionaron como vectores de propagación del movimiento opositor a las dictaduras. En ese marco también se organizaron exposiciones de obras de arte solidarias que se presentaron en diferentes países, cuyo caso emblemático fue el Museo Internacional de la Resistencia de Chile (LEBEAU, 2020), pero que, a su vez, también inspiró otras iniciativas como las vinculadas a Palestina, Sudáfrica y Nicaragua (SALTI \& KHOURI, 2015).

Este trabajo presenta un análisis comparado sobre el efecto, la significación y legado de las estrategias culturales y, en particular, de la producción gráfica, contrarias a los regímenes dictatoriales del Cono Sur llevadas a cabo desde Suecia y Francia, con un especial énfasis en los casos de los exiliados de Chile y Argentina, dado que fueron los colectivos mayoritarios procedentes de esa región. En el estudio se observa que mientras los exiliados procedentes del Cono Sur intentaban debilitar a los regímenes dictatoriales desde el espacio público transnacional convocando un apoyo externo, sus aliados europeos reinterpretaban en términos nacionales e internacionalistas esas demandas apelando a la sensibilidad local. Para ello evocaban sus propias experiencias traumáticas del pasado reciente, tales como la Segunda Guerra Mundial y los efectos del nazismo especialmente en Francia, o bien otros ejemplos de trascendencia internacional y en los que los propios ciudadanos de esos países se habían implicado directa o indirectamente, como la Guerra Civil española, el conflicto bélico en Vietnam y la ocupación de Palestina, entre otros. La referencia a esas últimas experiencias fue particularmente notoria en el caso de Suecia, dada su neutralidad en todos los conflictos 
europeos que tuvieron lugar después de las guerras napoleónicas a comienzos del siglo XIX.

Con el fin de estudiar las estrategias artísticas de denuncia a los regímenes dictatoriales del Cono Sur llevadas a cabo desde Francia y Suecia, se presenta, en primer lugar, el escenario ideológico europeo de finales de las décadas de los años sesenta y comienzos de los setenta, y, en segundo lugar, las principales características del exilio en los dos países analizados. En un tercer momento, se da paso a las particularidades de ambos casos con el fin de ponderar las similitudes y, para finalizar, se expone una reflexión comparativa de las respectivas experiencias.

\section{El clima político de 1968 y el surgimiento de la nueva izquierda}

A fines de los años sesenta se evidenció un fuerte desgaste de las izquierdas tradicionales - de los partidos socialista y comunista- especialmente en la juventud. A su vez, surgieron nuevas posiciones políticas que incluían consignas alternativas a las conocidas hasta entonces, por lo general impulsadas por sectores progresistas de la intelectualidad y las organizaciones estudiantiles. Sin embargo, la revuelta de la capital francesa en 1968, así como las manifestaciones que se sucedieron el mismo año en distintas partes del mundo como en Italia, Suecia, Japón, y México, entre otros, fue la explosión de un malestar que se venía gestando desde la segunda mitad de la década de los años cincuenta, momento en el que se fundó la revista New Left Review (HALL, 2010). Fue en ese momento cuando empezaba a tomar posición la causa tercermundista, vigorizando la concepción del internacionalismo que solidarizaba y apoyaba a las causas descolonizadoras de los movimientos de liberación nacional de Asia y África y, algo más tarde, empezó a denunciar asimismo el neocolonialismo en América Latina.

A diferencia de las experiencias anteriores, estas tendencias recogían las necesidades y las luchas procedentes de distintas partes del planeta. Es decir, las injusticias y los males que se debían combatir en todos los países tenían esencialmente una misma causa. Las reivindicaciones de la clase obrera daban paso a la denuncia del imperialismo o neocolonialismo, la defensa del medio ambiente, y la igualdad de 
derechos en temas de etnicidad y género. La diversificación de las consignas y los debates ideológicos, claramente ampliaron el espectro combativo, multiplicando las causas y motivos por los cuales era necesario organizarse. A ello se denominó la nueva izquierda. Asimismo, y en contra de lo que se podría haber esperado, esta corriente también criticó abiertamente la política exterior soviética, especialmente por las intervenciones que se habían producido inicialmente en Hungría (1956) y más tarde en Checoslovaquia (1968), cuando sus respectivos gobiernos intentaron tomar distancia de las directrices de Moscú. La represión ejercida por las tropas soviéticas acabó desencantando a un sector importante de los sectores progresistas de Occidente.

Argelia, Vietnam y Cuba se convirtieron en nuevos focos de atracción y posicionamiento político que convocaban a militantes de izquierda a involucrarse con sus causas. En estos años, en los entornos militantes europeos, se expandió el anticolonialismo y la solidaridad con los movimientos de liberación africana. En particular en Francia, un antecedente que impactó contundentemente en la militancia fue la Guerra de independencia de Argelia (1954-1962), que provocó apoyo al interior de la metrópoli por diversos medios a esa causa: transportando aportes económicos, armas, refugiando militantes, o denunciando públicamente los abusos de las fuerzas armadas francesas (HAMON \& ROTMAN, 1979; RIOUX \& SIRINELLI, 1992; PATTIEU, 2001).

En ese revulsivo clima, el compromiso con causas lejanas emparentó las injusticias. Así, acontecimientos tan distantes que iban desde la Revolución cubana a la Guerra en Vietnam, despertaron la solidaridad internacional. Del mismo modo que treinta años antes, la Guerra Civil española (1936-1939) había motivado el compromiso, y hasta la participación directa, de personas de buena parte de los países del mundo (MORADIELLOS, 2001). Entre ellos fueron a combatir a suelo español cientos de suecos (CAMACHO PADILLA \& ASUNCIÓN CRIADO, 2018) y miles de franceses, los cuales formaron parte, junto con aproximadamente 35.000 voluntarios extranjeros de alrededor de 50 países (LUGSCHITZ, 2019), de las Brigadas Internacionales ${ }^{8}$. La

\footnotetext{
${ }^{8}$ Este contingente, organizado en Moscú, tenía el objetivo de defender la Segunda República del ejército rebelde dirigido por el general Francisco Franco. El principal contingente, de aproximadamente un cuarto del total, eran ciudadanos franceses (SKOUTELSKY, 1998).
} 
experiencia de internacionalismo y solidaridad desatada durante el conflicto español, la cual estuvo acompañada de una enorme producción gráfica hasta entonces desconocida (LEFEBVRE-PEÑA, 2013), fueron recuperadas o reproducidas de manera casi idéntica con las que se llevaron a cabo inicialmente con Vietnam, pero muy especialmente con los países latinoamericanos entre las décadas de los años sesenta y ochenta. Asimismo, la recepción de los exiliados republicanos marcó el camino y creó estrategias de colaboración con la población local que sirvieron de ejemplo para quienes llegaron más tarde de Latinoamérica.

Una diferencia importante entre las causas de Vietnam, por un lado, y España y los países latinoamericanos, por el otro, fue la participación de actores procedentes de estos territorios. A pesar de que Vietnam había sido colonia francesa, la comunidad vietnamita residente en Francia, y especialmente aquella que participó en las actividades de solidaridad, fue insignificante. $\mathrm{Y}$ en el caso sueco fue totalmente inexistente. Sin embargo, tanto Francia como Suecia, se convirtieron en destinos significativos de exiliados procedentes de España y Latinoamérica, lo cual hizo visible de manera más clara y directa, a los conjuntos de sus sociedades, las consecuencias que la violencia y el terror tenía en la población, pues entre los exiliados se encontraban personas que habían sido detenidas, torturadas o tenían familiares cercanos que habían sufrido este tipo de vejaciones. Además, estos colectivos participaron masivamente en las actividades de solidaridad, ya fueran manifestaciones callejeras o actos culturales, lo cual permitía tener un contacto directo con la población autóctona, sueca y francesa respectivamente. Cabe destacar, a su vez, que entre los exiliados se encontraban numerosos artistas, músicos, escritores e intelectuales de distinta índole, quienes pusieron sus destrezas en servicio de la lucha contra los regímenes dictatoriales. Así, la producción cultural por estas causas, en el sentido amplio, fue enorme, dado que a las realizadas por la población local se juntaba la de los recién llegados, superando de manera sobrada toda la producción en denuncia de las injusticias que habían ocurrido o estaban ocurriendo en otras zonas del planeta. 


\section{El fenómeno del exilio en el Cono Sur}

Las principales oleadas de exiliados latinoamericanos se fueron sucediendo desde el golpe de estado en Brasil en 1964, de Uruguay y Chile en 1973 y posteriormente, en 1976 en Argentina. Las características de cada uno de ellos despertaron distinto nivel de compromiso. El caso brasileño no repercutió de manera repentina y masiva en Europa porque la mayoría de quienes se vieron forzados a salir del país, se establecieron en un primer momento en la misma región, en tanto buena parte las democracias seguían vigentes. La salida de los brasileños hacia Europa fue lenta y progresiva. Quienes se dirigieron a Francia lo hacían por afinidad cultural y por tener conocimientos previos del idioma, lo que demuestra que pertenecían a un estrato social con alto nivel educativo y un rango socioeconómico medio o alto. Fue así como llegaron a ese país, por ejemplo, el fotógrafo Sebastião Salgado y su esposa en 1969. En sus memorias, Salgado relata lo siguiente:

Participamos en todas las manifestaciones y en todas las acciones de resistencia a la dictadura y estábamos, junto con nuestros camaradas, salvajemente decididos a defender nuestras ideas. Era evidentemente muy peligroso y, llegados a ese punto de compromiso, teníamos que pasar a la clandestinidad. Pero nuestro grupo decidió que los más jóvenes debían irse a estudiar al extranjero, a la vez que continuarían actuando desde el exterior, mientras que los que tenían más madurez pasarían a la clandestinidad.

[...] Recuerdo el alivio que sentimos al dejar el último puerto atrás, cuando el barco se alejó definitivamente de la costa brasileña en dirección a Francia. Francia era un lugar muy atractivo para nosotros los brasileños. (SALGADO, 2014, p. 21).

El número de exiliados tampoco fue numéricamente tan significativo como lo serían años más tarde los contingentes de chilenos y argentinos. Chile fue un destino importante para numerosos profesionales brasileños que fueron bien recibidos por el gobierno del Partido Demócrata Cristiano (1964-1970). Se encontraban entre ellos varios economistas defensores de la teoría de la dependencia, puesto que Santiago de 
Chile era la ciudad en la que se encontraba la sede central de la Comisión Económica para América Latina y el Caribe (CEPAL), dependiente de la Organización de las Naciones Unidas (SÁENZ CARRETE, 2014). A Chile llegaron también intelectuales procedentes de las humanidades y las tendencias progresistas del cristianismo, conocida como la Teología de la Liberación, tras la celebración de la Conferencia Episcopal de Medellín de 1968. En ese contingente figura Paulo Freire, quien residió en el país entre 1964 y 1969, y, además, se involucró de lleno, al igual que sus compatriotas, en el programa de reformas llevadas a cabo por Eduardo Frei Montalva en la denominada "Revolución en Libertad" (CABALUZ \& AREYUNA-IBARRA, 2020). ${ }^{9}$

Tras el golpe de Estado en Uruguay de junio de 1973, se reprodujo una situación similar, pues la mayoría de los exiliados de esa nacionalidad se fueron a países latinoamericanos. Entre todos ellos, Chile fue su principal destino (ALDRIGHI \& WAKSMAN, 2015) aunque también en estas fechas llegaron exiliados o activistas de izquierda de otros lugares fundamentalmente por dos motivos. En primer lugar, por la política de acogida del gobierno de la Unidad Popular (1970-1973), y, en segundo lugar, por que un sector importante de activistas quería conocer de cerca, y ser parte, del proceso revolucionario chileno. Así, durante los años de la presidencia de Salvador Allende, Chile se convirtió en el principal polo de atracción de militantes latinoamericanos de izquierda.

Una vez ejecutado el golpe del general Augusto Pinochet, las posibilidades de establecerse en Sudamérica no eran del todo favorables, dado que en varios países ya estaban instaurados regímenes dictatoriales. Inicialmente numerosos chilenos viajaron a Perú o Argentina, aunque al incrementarse las prácticas represivas en aquellas tierras entre 1975 y 1976, en buena medida se vieron obligados a buscar un nuevo destino. Las opciones más seguras en la región fueron Colombia, Venezuela, Cuba y, muy especialmente, México. Estos países también se convirtieron en destinos con comunidades significativas de chilenos, argentinos, uruguayos y brasileños. Tras la revolución sandinista de 1979, Nicaragua también albergó a un grupo importante de

\footnotetext{
${ }^{9}$ Durante su permanencia en Chile, Freire escribió su primera gran obra, La educación como práctica de la libertad (1969).
} 
exiliados del Cono Sur, quienes se incorporaron rápidamente a puestos gubernamentales de distinta índole.

A raíz de los golpes de Chile y Argentina, también llegaron a Europa latinoamericanos con otras nacionalidades que no podían volver a sus países de origen por razones políticas. De ese modo, bolivianos, uruguayos y brasileños, entre otros, se establecieron, junto con chilenos y argentinos, en los distintos países europeos. En la mayoría de los casos, ya contaban con documentos que acreditaban su condición de refugiados, los cuales habían sido emitidos por los gobiernos de Chile o Argentina.

Entre todos los golpes de Estado que tuvieron lugar en Latinoamérica, el caso chileno fue, indiscutiblemente, el que mayor impacto y visibilidad cobró a nivel internacional. El procedimiento violento generó una profusión de imágenes que circularon ampliamente por el mundo y acabaron volviéndose icónicas por su espectacularidad, como ocurrió con el propio bombardeo del Palacio de la Moneda, el levantamiento del cadáver del presidente Allende, y el confinamiento de presos políticos en el Estadio Nacional, entre muchas otras. La sensibilidad ante la dictadura chilena se correspondía al entusiasmo que había generado la experiencia de la Unidad Popular en la izquierda europea, que, frente a las suspicacias que despertaban las experiencias del Este, veían en Allende la esperanza de alcanzar el socialismo mediante vías democráticas.

En contraposición a la repercusión mediática del caso chileno, el golpe militar en Argentina se concretó sin grandes sobresaltos y, además, no fue del todo comprensible para las sociedades europeas por la especificidad política de ese país. Por una parte, el fenómeno del peronismo carecía de parangón en el panorama político local, generando confusión. Por la otra, el gobierno recientemente destituido, hasta entonces presidido por la viuda de Perón, "Isabel”, María Estela Martínez de Perón, había sido denunciado de violar derechos humanos. Para evitar sanciones y aislamiento internacional como el régimen de Pinochet, la cúpula militar se preocupó de ocultar las prácticas represivas que violaban el marco legal institucional, desobedeciendo así las normas propias por las que se regía la estructura policial, la cual actuaba, además, de manera simultánea. Por ello, la junta creó una compleja estructura clandestina del terror, 
en simultáneo a que activaba un potente aparato de comunicación y "acción psicológica" dentro del país de manera de crear consenso en la población local (RISLER, 2018) y fuera del mismo para contrarrestar las denuncias internacionales acusándolas de ser parte de una "campaña antiargentina"10 (FRANCO, 2008).

Asimismo, las acciones masivas de solidaridad y denuncia realizadas por los exiliados que procedieron de Chile prepararon de alguna manera el recibimiento de quienes huyeron de los golpes posteriores en la región, especialmente el perpetrado en Argentina. Con relación a este último caso, se debe destacar que la principal atención de los medios de comunicación de masas tuvo lugar con motivo de la Copa Mundial de Fútbol del año 1978, el cual fue un acontecimiento claramente instrumentalizado por la dictadura militar (BOLCHINSKY PINSÓN, 2018), que movilizó asimismo un significativo movimiento de boicot de naturaleza transnacional (FRANCO, 2008, REIN, 2019). Si bien no existían imágenes de las prácticas represivas, pero si testimonios de sobrevivientes, apareció una gran diversidad de producción gráfica relacionada con los estadios deportivos simulando campos de concentración similares a los que existieron en Alemania bajo el nazismo, a través de los cuales se denunciaban las violaciones a los derechos humanos que se estaban cometiendo en clandestinidad.

\section{Exiliados del Cono Sur en Suecia y Francia}

Las características de los exilios latinoamericanos en Suecia y Francia difieren en varios aspectos. Por lo general, Francia era un destino preferente para intelectuales y artistas, por su carácter de tradicional polo cultural. Por su parte, las generosas políticas receptivas de Suecia favorecieron la llegada de exilios de estrato obrero, así como figuras de las organizaciones armadas que no eran aceptadas en otros destinos ante el temor de que pudieran convertirse en "sujetos incontrolables", tal como eran designados en ese momento.

Tanto Suecia como Francia contaban con una importante tradición de país de refugio. Gracias a su neutralidad, Suecia se convirtió en un destino importante desde la

\footnotetext{
${ }^{10}$ En ambos casos eran los términos utilizados por las Fuerzas Armadas argentinas. 
Primera Guerra Mundial (1914-1918), y, sobre todo, tras la Revolución rusa (1917). Inicialmente recibió a exiliados de los países de la cuenca del Mar Báltico, a la que se sumaron durante la Segunda Guerra Mundial, refugiados de los otros países escandinavos y tanto de Europa Central como Oriental, desde donde continuaron llegando durante la Guerra Fría. No obstante, también recibieron refugiados del sur de Europa, como Portugal, España o Grecia. La presencia de exiliados no europeos no se volvió verdaderamente visible hasta finales de la década de los años sesenta y comienzos de los setenta, a partir de los golpes de Estado en América Latina pero también de las guerras civiles de varios países africanos y asiáticos.

Francia, por el contrario, había sido un destino elegido por exiliados de prácticamente todo el mundo desde el siglo XIX. Tras recibir contingentes de refugiados de países como España, Portugal, Italia, Grecia, así como de países de Europa Oriental, llegaron numerosos latinoamericanos, generalmente liberales o de sectores progresistas. Más tarde lo harían desde otras partes de África y Asia. En sus memorias, Salgado describe sus impresiones sobre Francia, las cuales eran compartidas por la mayor parte de la intelectualidad latinoamericana:

Francia era para nosotros ineludible: era la patria de los derechos humanos y de la democracia. Era la alternativa a la elección entre el comunismo y Estados Unidos. Admirábamos a los comunistas por ser los principales apoyos de la izquierda, pero teníamos dudas sobre cierto oscurantismo del que hacían alarde. En cuanto a nuestra confianza en los Estados Unidos, era absolutamente cero: era la causa de la represión que nos oprimía. Nunca habían entablado vínculo alguno con nada que fuera popular o democrático. Ayudaban siempre a mantener en su sitio a aquellos que tenían más poder y poseían armas. Francia era para nosotros el país de las ideas democráticas, aunque también de las económicas.

[...] Fue en Francia donde aprendimos la solidaridad y, cuando uno se acerca a ella, se queda. Nos preocupamos por los brasileños que llegaban completamente destrozados por la dictadura. Muchos habían sido torturados. Las organizaciones de izquierda conseguían sacar a algunos a través de Argentina y Uruguay, pero llegaban rotos, física y mentalmente. (SALGADO, 2014, p. 22-23). 
Los autores Rojas y Santoni (2013) describen la distribución de los exiliados chilenos en el mundo en función a su militancia política. En su trabajo, argumentan que su ubicación dependía en buena medida de la sintonía ideológica existente entre sus organizaciones con los distintos gobiernos de turno, especialmente de Europa Oriental y Occidental. Fue así como militantes del Partido Comunista chileno se establecieron en la Unión Soviética o países satélites, mientras que sectores más moderados lo hicieron en Italia o Francia. La distribución se debió también a numerosos otros factores, por ejemplo, las redes sociales de los perseguidos, sus condiciones económicas, y las propias coyunturas de los países receptores, puesto que no todos ellos tuvieron la misma actitud durante los años que duró la dictadura. A partir de la crisis de la deuda, y hasta el final de la dictadura, también salió de Chile un número importante de personas por razones económicas, quienes buscaron como destino países con alto nivel de desarrollo y buenas oportunidades laborales, razón por la que llegaron mayoritariamente a países como Suecia, Canadá o incluso Nueva Zelanda. Asimismo, otro factor determinante a la hora de planificar la salida de Chile fue la facilidad con la que podían optar la nacionalidad de un país europeo, o si ya gozaban de doble nacionalidad, pues en ese caso, la embajada del país correspondiente en principio debía brindarle protección, aunque ello estuvo condicionado, a su vez, de la propia voluntad de sus funcionarios. Pero, en definitiva, de los cincuenta países en los que se distribuyeron los exiliados chilenos, Francia y Suecia fueron los mayoritarios receptores en Europa.

$\mathrm{Si}$ analizamos comparativamente las cifras de residentes latinoamericanos en Suecia, en la tabla 1 se puede observar cómo a inicios de la década de los años setenta, el número de residentes argentinos era superior al de chilenos. Sin embargo, una vez que se produjo el golpe de Estado de 1973, estas cifras se invirtieron, colocando a la comunidad chilena muy por encima de la argentina, incluso en los años posteriores al derrocamiento del gobierno de Isabel Perón en 1976. Esta desigualdad numérica significó que las actividades de solidaridad por la causa chilena siguieron siendo dominantes en Suecia, y, además, por la mayor duración de la dictadura, la cual puso fin 
en 1990, también mucho más extensa temporalmente. ${ }^{11}$ Mientras que la mayor parte de los pocos exiliados argentinos acabaron regresando a su país tras la recuperación de la democracia, los chilenos -al haber permanecido casi dos décadas- encontraron su retorno más dificultoso.

Tabla 1: Residentes latinoamericanos en Suecia por año

\begin{tabular}{|l|c|c|c|c|c|c|}
\hline \multicolumn{1}{|c|}{ PAÍ́S } & $\mathbf{1 9 7 0}$ & $\mathbf{1 9 7 5}$ & $\mathbf{1 9 8 0}$ & $\mathbf{1 9 8 5}$ & $\mathbf{1 9 8 7}$ & $\mathbf{1 9 9 0}$ \\
\hline Argentina & 632 & 640 & 2.211 & 2.326 & 2.278 & 2.433 \\
\hline Brasil & 468 & 843 & 1.091 & 1.435 & 1.565 & 2.162 \\
\hline Chile & 181 & 1.663 & 8.256 & 13.283 & 17.887 & 27.841 \\
\hline Uruguay & 71 & 447 & 2.101 & 2.624 & 2.435 & 2.447 \\
\hline $\begin{array}{l}\text { América } \\
\text { Latina }\end{array}$ & 2.300 & 5.290 & 17.206 & 26.247 & 31.812 & 47.980 \\
\hline
\end{tabular}

Fuente: Statistikmyndigheten [https://www.scb.se]

En la tabla 2 se observa que, desde el golpe de Estado de Pinochet, el número de chilenos llegados a Suecia siempre se mantuvo muy por encima de los argentinos y también de otras nacionalidades latinoamericanas, a pesar de ser un país con una población relativamente pequeña en términos cuantitativos. Dentro del periodo en el que los regímenes dictatoriales coincidieron temporalmente, fue el año 1978 cuando más chilenos y argentinos llegaron a Suecia. A partir de ahí, se fueron reduciendo progresivamente en ambos casos. Tras la recuperación de la democracia, la cifra de argentinos que llegaban al país anualmente prácticamente no pasó la centena, a excepción de $1986^{12}$, mientras que los chilenos se dispararon notablemente entre 1987 y

\footnotetext{
11 Tanto por el alto número de refugiados chilenos que se establecieron en Suecia, como por la duración de la dictadura, se crearon numerosas asociaciones culturales y deportivas integradas por chilenos en distintas partes del país (BILDT, 1988, pp.180-187).

${ }^{12}$ Canelo (2007) estimó entre 1.600 y 2.000 el número de exiliados políticos argentinos que se instaló en Suecia durante los años del terrorismo estatal en Argentina. En tanto existía una débil tradición inmigratoria de argentinos en ese país, la cantidad de residentes de esta nacionalidad se multiplicó por cuatro después del golpe de Estado de marzo de 1976 -pasando de 640 en 1975 a 2.221 en 1980- y por
} 
1989. A causa de su alto número en Suecia, país con una población relativamente pequeña, su visibilidad fue importante. Los motivos de fondo de esta migración masiva durante los últimos años de la década de los ochenta fueron principalmente económicos. La diferencia entre los dos casos estudiados se debe esencialmente a que, en términos globales, los exiliados argentinos constituyeron una cifra menor que la de los chilenos. ${ }^{13}$ También se instalaron mayoritariamente en países en los que les resultaría más fácil obtener la residencia o nacionalidad, y, además, pudieran insertarse profesionalmente dentro de sus áreas de conocimiento. Por esta razón, dentro de Europa se concentraron mayoritariamente en España, Francia e Italia.

Tabla 2: chilenos y argentinos llegados a Suecia por año

\begin{tabular}{|l|c|c|c|c|c|c|c|c|c|}
\hline \multicolumn{1}{|c|}{ AÑOS } & $\mathbf{1 9 7 3}$ & $\mathbf{1 9 7 4}$ & $\mathbf{1 9 7 5}$ & $\mathbf{1 9 7 6}$ & $\mathbf{1 9 7 7}$ & $\mathbf{1 9 7 8}$ & $\mathbf{1 9 7 9}$ & $\mathbf{1 9 8 0}$ & $\mathbf{1 9 8 1}$ \\
\hline Chilenos & 81 & 688 & 764 & 935 & 1.732 & 1.808 & 1.400 & 1.283 & 1.248 \\
\hline Argentinos & 56 & 47 & 87 & 163 & 376 & 571 & 358 & 308 & 185 \\
\hline
\end{tabular}

\begin{tabular}{|l|c|c|c|c|c|c|c|c|c|c|}
\hline \multicolumn{1}{|c|}{ AÑOS } & $\mathbf{1 9 8 2}$ & $\mathbf{1 9 8 3}$ & $\mathbf{1 9 8 4}$ & $\mathbf{1 9 8 5}$ & $\mathbf{1 9 8 6}$ & $\mathbf{1 9 8 7}$ & $\mathbf{1 9 8 8}$ & $\mathbf{1 9 8 9}$ & $\mathbf{1 9 9 0}$ & $\begin{array}{c}\text { Total } \\
\text { periodo }\end{array}$ \\
\hline Chilenos & 1.094 & 1.053 & 1.017 & 1.164 & 2.206 & 2.772 & 2.954 & 5.878 & 1.611 & $\mathbf{2 9 . 6 8 5}$ \\
\hline Argentinos & 108 & 127 & 79 & 92 & 63 & 114 & 71 & 66 & 100 & $\mathbf{2 . 9 7 1}$ \\
\hline
\end{tabular}

Fuente: Statistikmyndigheten [https://www.scb.se]

En lo que respecta a Francia, se estima que entre 1964 y 1979 llegaron al país 15.000 migrantes políticos latinoamericanos, de los cuales 10.000 obtuvieron la condición de refugiados (SÁENZ CARRETE, 1995). Si los migrantes argentinos fueron 128.217 en el ciclo $1960-1970$ y entre 236.138 y 339.329 en el de 1970-1980

cinco en relación con 1970. Doorm (2013) destaca que tras la restauración democrática en Argentina el número de residentes de ese país en Suecia se mantiene relativamente estable.

${ }^{13}$ No hay cifras claras del número de exiliados chilenos a nivel global. Los distintos especialistas entregan datos que oscilan entre 200.000 y 1.000 .000 de casos (Aguirre Argomedo \& Chamorro Martínez, 2008, p. 45-46). 
(FRANCO, 2008, p. 39), sólo unos 2.000 habrían sido exiliados por razones políticas en Francia durante el período dictatorial y, dentro de ese grupo, 941 obtuvieron la condición de refugiados (p. 132). En cuanto al flujo de chilenos en Francia, Gaillard (1997) estima que dentro del periodo 1974-1979 fueron 3.231 los exiliados y entre los años 1980 y 1988 la cifra sería de 1.430. Sin embargo, el Alto Comisariado para los Refugiados de las Naciones Unidas (HCR) registra 2.044 para el primer período y 809 para el segundo (PROGNON, 2002). Jammet Arias (2020) analizó los 889 expedientes de chilenos existentes en los archivos administrativos de la Oficina Francesa Para Refugiados y Apátridas (OFPRA) a través de los cuales pudo rastrear los itinerarios previos a su ingreso a Francia, pasando -en buena parte- por un exilio en Argentina, de los cuales un tercio ingresó a Europa por España. Esta autora identifica una primera ola de chilenos que llegó directamente en 1973/4 a través de las embajadas, una segunda ola en torno a 1976 con el golpe de Estado en Argentina y una tercera a partir del ciclo 1981/2 marcada por la crisis económica (JAMMET ARIAS, 2020).

Tabla 3: Residentes y refugiados chilenos en Francia por bienio

\begin{tabular}{|l|c|c|c|c|c|c|c|c|c|}
\hline & $\mathbf{1 9 7 3}$ & $\mathbf{1 9 7 5}$ & $\mathbf{1 9 7 7}$ & $\mathbf{1 9 7 9}$ & $\mathbf{1 9 8 1}$ & $\mathbf{1 9 8 3}$ & $\mathbf{1 9 8 5}$ & $\mathbf{1 9 8 7}$ & $\mathbf{1 9 8 9}$ \\
$\mathbf{1 9 7 4}$ & $\mathbf{1 9 7 6}$ & $\mathbf{1 9 7 8}$ & $\mathbf{1 9 8 0}$ & $\mathbf{1 9 8 2}$ & $\mathbf{1 9 8 4}$ & $\mathbf{1 9 8 6}$ & $\mathbf{1 9 8 8}$ & $\mathbf{1 9 9 0}$ \\
\hline Residentes & 1.218 & 2.781 & 4.498 & 6.014 & 7.360 & 8.585 & 8.944 & 7.584 & 7.868 \\
\hline Refugiados & 409 & 1.162 & 2.149 & 3.231 & 4.134 & 4.977 & 5.526 & 4.545 & 4.661 \\
\hline
\end{tabular}

Fuente: Ministère de l'intérieur et de l'aménagement du territoire (Gaillard, 1997, p. 39)

Tabla 4: Residentes latinoamericanos en Francia

\begin{tabular}{|l|c|c|c|c|}
\hline \multicolumn{1}{|c|}{ ORÍGEN } & $\mathbf{1 9 6 8}$ & $\mathbf{1 9 7 5}$ & $\mathbf{1 9 8 2}$ & $\mathbf{1 9 9 0}$ \\
\hline Argentino & 1.680 & 2.090 & 3.724 & 3.104 \\
\hline Brasileño & 2.004 & 2.940 & 3.808 & 6.301 \\
\hline
\end{tabular}




\begin{tabular}{|l|c|c|c|c|} 
Chileno & 644 & 2.360 & 6.272 & 7.468 \\
\hline Latinoamericano & 5.260 & 15.470 & 29.178 & 41.714 \\
\hline
\end{tabular}

Fuente: Censos poblacionales del Institut National de la statistique et des Études Économiques.

En resumen, las estimaciones sobre los exiliados argentinos en Francia y Suecia rondaron en ambos casos cifras similares, que se situaron en torno a los 2.000 durante el período dictatorial, siendo importantes destinos europeos, aunque no los principales como sí lo fueron para los chilenos. En cuanto a la cantidad que obtuvieron el carácter de refugiados en Francia, los chilenos quintuplicaron a los argentinos, y en términos proporcionales a la población total de su país de origen fue aún más significativo, pues en 1980 la población de Argentina era de 27.900.000 y la de Chile 11.400.000. Con relación al país receptivo, la diferencia de esa presencia latinoamericana fue abrumadora, ya que Francia la población rondaba los 55.161.000 de personas en 1980 mientras que Suecia sólo contaba con 8.310 .000 de habitantes ${ }^{14}$.

Entre las víctimas de la represión de Chile y Argentina, fue en el segundo país donde había una mayor cantidad de personas con doble nacionalidad, o que podían optar a ella. El motivo de fondo era la propia recepción migratoria que había experimentado Argentina en las décadas anteriores, con una población de origen europeo más alta que la existente en Chile. Fundamentalmente se trató de descendientes de inmigrantes italianos y españoles, aunque también de numerosas otras nacionalidades. Los gobiernos de estos países tuvieron que prestar una atención especial a estos casos, ofreciéndoles la posibilidad de establecerse en sus territorios indistintamente su militancia política (GARCÍA GUTIÉRREZ, 2013).

En los casos de Francia y Suecia respectivamente se dieron varias diferencias significativas. En comparación con España e Italia, son escasos los suecos que sufrieron directamente la represión. En el caso sueco, algunos jóvenes cooperantes fueron detenidos y torturados en los días inmediatos al golpe de Estado en Chile, siendo puestos en libertad gracias a la gestión del embajador Harald Edelstam (CAMACHO

\footnotetext{
${ }^{14}$ Fuente: Banco Mundial. 
PADILLA, 2006). En el caso argentino, en cambio, si bien no hay conocimiento de ciudadanos suecos que sufrieran detenciones por motivos políticos, existen dos casos de desaparecidos. El primero de ellos fue Svante Grände, quien desapareció después de una redada militar que tuvo lugar en la provincia de Tucumán en 1975. Poco antes, Grände había entrado a formar parte del Ejército Revolucionario del Pueblo (ERP) tras su huida de Chile. El segundo de ellos fue Dagmar Hagelin, ciudadana argentina con nacionalidad sueca recibida por su lado paterno. Hagelin, de diecisiete años, fue detenida por error durante un operativo en Buenos Aires y llevada a la Escuela de Mecánica de la Armada (ESMA), último lugar donde fue vista con vida. En el caso de Grände, ni su propia familia ni las autoridades suecas se preocuparon de presionar al gobierno argentino para esclarecer lo ocurrido. El caso de Hagelin fue muy sonado en Suecia, dado que se trataba de una adolescente sin vinculación alguna con las organizaciones armadas. Inicialmente, la Embajada de Suecia en Buenos Aires no se preocupó por el caso, pero por insistencia de su padre, Ragnar Hagelin, el gobierno de este país solicitó en numerosas ocasiones información a su homólogo argentino ${ }^{15}$. En cuestión de poco tiempo, Ragnar Hagelin tuvo que instalarse en Estocolmo por las constantes amenazas recibidas. ${ }^{16}$

En lo que se refiere a las víctimas francesas, en Chile se produjeron cuatro víctimas mortales con esa nacionalidad, dos nacidas en Francia y dos en Chile (COMISIÓN NACIONAL DE REPARACIÓN Y RECONCILIACIÓN, 1992, p. 551). En Argentina encontramos un total de 18 desaparecidos franceses ${ }^{17}$, de los cuales los casos más resonantes fueron los de las dos monjas francesas Alice Domon y Léonie Duquet, vinculadas a las Madres de la Plaza de Mayo, que generaron -aunque sin éxitoinsistentes presiones diplomáticas (CATOGGIO \& FELD, 2020). Hasta la fecha, no se dispone de datos públicos ni en Chile ni en Argentina sobre el número de personas con

${ }^{15}$ Los documentos desclasificados de Cancillería Argentina demuestran las múltiples instancias de presión y de deterioro de las relaciones de las autoridades suecas ante la negativa del gobierno argentino de aclarar la situación. Ver, por ejemplo, cable 138/139 del 18/04/1980, disponible en:

http://desclasificacion.cancilleria.gob.ar/userfiles/documentos//OEA-ONU-

21697/80AH012707A_060.pdf

${ }^{16}$ Para conocer con detalle el caso de Dagmar Hagelin, véase Hagelin (1984)

${ }_{17}$ Para profundizar en cada uno de los casos, ver volante publicado por la Embajada de Francia en Argentina en el aniversario de los 30 años del golpe de Estado (2006).

http://www.memoriaabierta.org.ar/p_ddhh/images/8_europeos/lista_franceses.pdf 
nacionalidad francesa y sueca que sobrevivieron la tortura o fueron presos políticos ${ }^{18}$. En varios de esos casos, tras regresar a sus respectivos países, rápidamente relataron las atrocidades vividas en los medios de comunicación, y, además, por haber experimentado en carne propia el horror, desarrollaron un compromiso profundo con la defensa de los derechos humanos que perduró hasta su muerte. ${ }^{19}$

Asimismo, los medios suecos y franceses cubrieron en detalle casos de ciudadanos de esos países que fueron torturados, asesinados y desaparecidos en el Cono Sur. En consecuencia, sus connacionales pudieron conocer y sentir de cerca las características de la represión, a la vez que se percataron que ellos, como pueblo, también se veían directamente afectados. Estas víctimas personificaron en múltiples ocasiones las campañas de solidaridad que se llevaron a cabo en Suecia y Francia, especialmente en las demandas de verdad y justicia. Del mismo modo, sus rostros fueron reproducidos en pancartas y expuestos con gran frecuencia como banderas de esas demandas.

\footnotetext{
${ }^{18}$ Entre ellos el presidente de la Asociación de Desaparecidos y Presos en Argentina y Uruguay, JeanPierre Lhande, fue torturado e interrogado en francés en la casa de sus padres en Buenos Aires cuando un grupo de hombres armados irrumpió en busca de su hermano. Este último, Michel Lhande, permaneció siete años preso a disposición del Poder Ejecutivo Nacional de Argentina.

${ }^{19}$ Entre los suecos que fueron víctimas de la tortura en Chile se encontraron el economista Henrik Janbell y el periodista Bobi Sourander, que en ese momento era el corresponsal del diario Dagens Nyheter, el de mayor tirada a nivel nacional. Ambos escribieron a lo largo de su vida decenas de artículos sobre el terrorismo de Estado en Chile.
} 


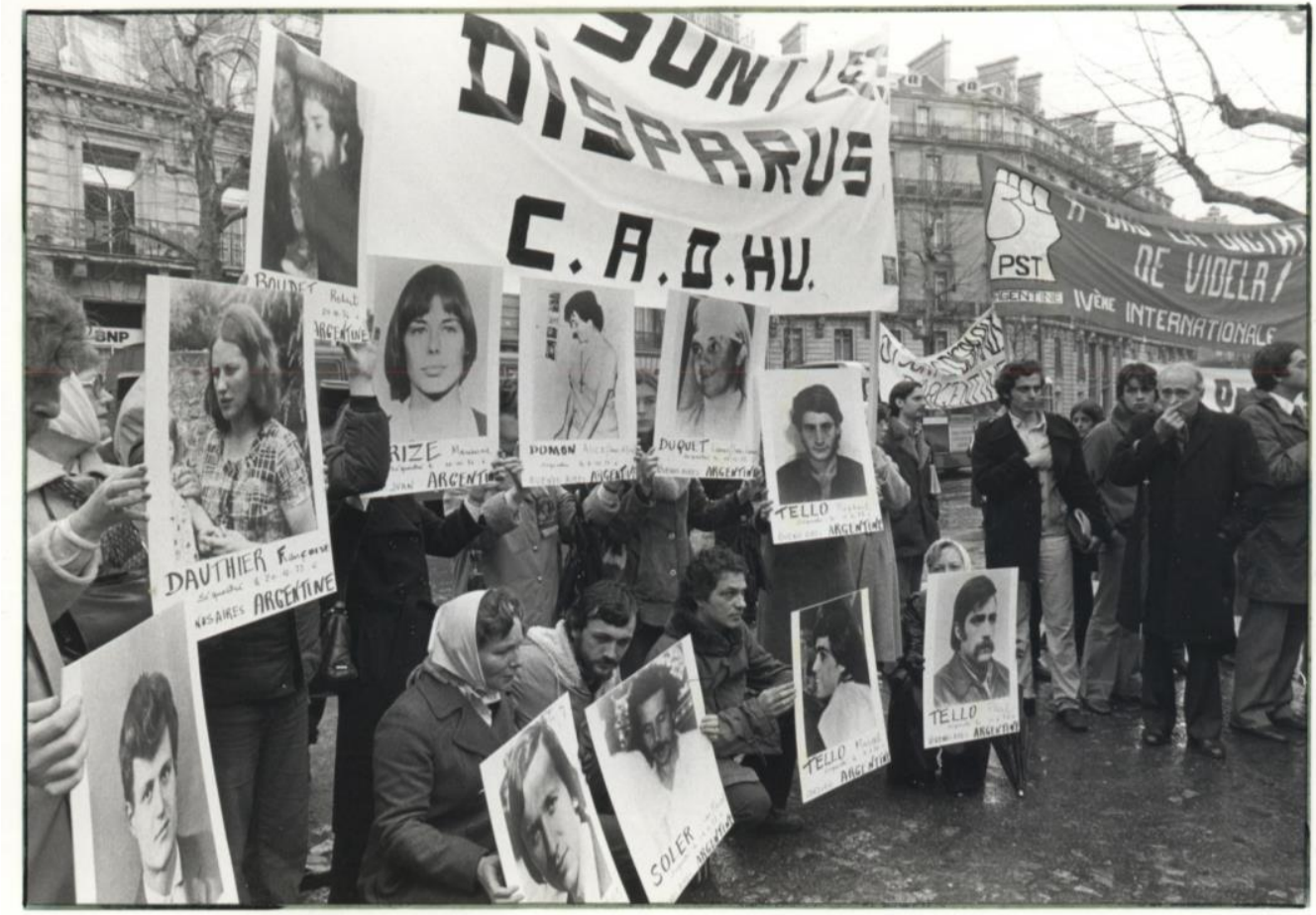

Fotografía $n^{\circ}$ 1: Pancartas de franceses desaparecidos en Argentina, manifestación frente a la Embajada Argentina en París. Fuente: Colección Nouveaux Droits de l'Homme, Archivo General de la Memoria (Argentina).

Acontecimientos como la desaparición de Dagmar Hagelin en Argentina a comienzos de 1977 y la celebración de la Copa del Mundo de Fútbol en 1978, intensificaron en Suecia la cobertura mediática de la situación de los derechos humanos en Argentina durante más de dos años. Los defensores de esos valores se decepcionaron profundamente de la selección nacional sueca, ya que sus jugadores no mostraron la más mínima sensibilidad por la situación que se estaba viviendo. Antes de partir respondieron con evasivas a los periodistas que les preguntaron sobre su posición respecto a la política argentina $\mathrm{y}$, al regresar, declararon haber pasado una estancia maravillosa en un país que se encontraba en plena normalidad (PEINADO, 2013).

\section{Revista Eletrônica da ANPHLAC}

Revista Eletrônica da ANPHLAC, ISSN 1679-1061, № 30, p.182-239, Jan./Jul., 2021. http://revista.anphlac.org.br 


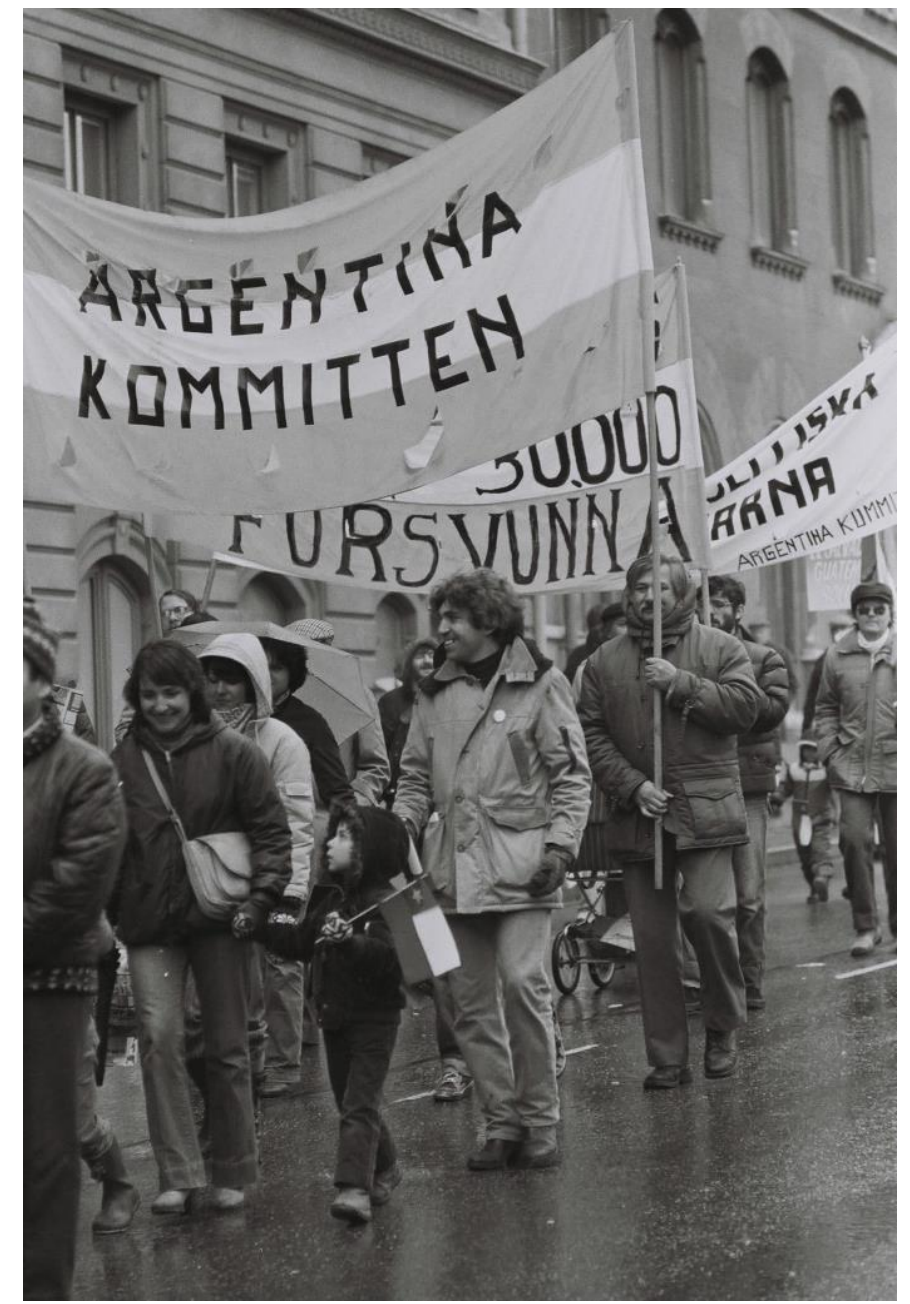

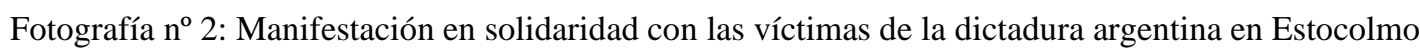
(1981). Fuente: Colección privada de Göran Sallnäs.

\section{La dimensión cultural de los movimientos de solidaridad con Chile y Argentina}

A lo largo de los periodos en los que Chile y Argentina estuvieron regidos por dictaduras militares, el movimiento de solidaridad pasó por distintas fases. Por sus propias características y sus temporalidades distintas no resulta posible trazar un marco similar para ambos casos. En primer lugar, el caso chileno fue mucho más extenso, ya que la solidaridad comenzó con el triunfo electoral de la Unidad Popular en 1970 para denunciar públicamente el boicot de Estados Unidos y los sabotajes llevados a cabo por 
sectores de ultraderecha, y terminó en 1990 con la recuperación de la democracia. En un primer momento inmediato al golpe de Estado, las primeras acciones vinieron impulsadas por ciudadanos originarios de los dos países europeos con la participación de algunos latinoamericanos o ciudadanos de otros países sensibilizados por lo ocurrido. En el caso argentino, en cambio, cuando se produjo el golpe de Estado ya vivían en Europa comunidades relativamente numerosas de exiliados del Cono Sur, inclusive argentinos que habían tenido que escapar a causa de las prácticas represivas iniciadas durante el gobierno de Isabel Perón ${ }^{20}$. Si bien participaron ciudadanos suecos y franceses en las movilizaciones, la presencia de sudamericanos fue muy significativa desde el primer momento. Tanto Chile ${ }^{21}$ como Argentina tras sus respectivos golpes de Estado captaron una gran atención mediática por parte de Suecia y Francia, lo cual se refleja en el número de reportajes que realizaron periodistas de sus canales de televisión, la SVT y France Télévision, si bien es cierto que el caso chileno sobresalió con amplia resonancia por la propia violencia que practicaron abiertamente las fuerzas de seguridad. ${ }^{22}$

Posteriormente, las coyunturas vinieron de la mano de los propios procesos internos y externos de las respectivas dictaduras. En el caso chileno, principalmente con motivo de la detención o ejecución de alguna figura política o social importante, encuentros deportivos tales como el partido de tenis de la Copa Davis celebrado en Båstad en 1975 (en este caso fundamentalmente en Suecia y países limítrofes), la

\footnotetext{
${ }^{20}$ Previo al golpe, ya existía en Francia el Comité de Apoyo a las luchas del Pueblo Argentino (Comité de Soutien aux Luttes du Peuple Argentin, CSLPA,) fundado en 1975 por, entre otros, François Gèze. Este ingeniero francés, que había vivido en Buenos Aires entre octubre de 1973 y principios de 1975, y entablado relaciones con militantes locales, denunció tempranamente la represión clandestina en ese país, tanto en los medios como en un libro (GÈZE \& LABROUSSE, 1975). Su coautor, Doctor en Sociología y Letras, también había residido entre 1965 y 1970 en el Cono Sur -en su caso en Montevideo- y ya había publicado en 1971 un libro sobre Tupamaros y en 1972 otro sobre la experiencia de la Unidad Popular.

${ }^{21}$ El interés internacional por Chile, en realidad, comenzó desde el triunfo electoral de la Unidad Popular por el carácter revolucionario de su programa político, el cual, por primera vez en la historia, se iba a realizar siguiendo la legalidad constitucional. Por esta razón, periodistas y simpatizantes de numerosos países, viajaron a Santiago para conocer de cerca el proceso que se estaba poniendo en marcha. Así, fotógrafos suecos, como Karl Jagare, recorrieron el país para retratar lo que estaba sucediendo (JAGARE, 2009).

${ }^{22}$ En el centro audiovisual del Museo de la Memoria y los Derechos Humanos de Chile se pueden consultar todos estos reportajes. Imágenes de la televisión francesa se encuentran disponibles en los archivos del INA: https://www.ina.fr/video/I15125596/chili-coup-d-etat-du-11-septembre-1973video.html
} 
Constitución de 1980, la crisis económica de 1982 y las fuertes protestas sociales que generó, y el Plebiscito de 1988. En el caso argentino, se concentraron fundamentalmente en las desapariciones de ciudadanos suecos o franceses, el Mundial de fútbol de 1978, y, posteriormente, la Guerra de las Malvinas de 1982, aunque este hecho generó divisiones entre la comunidad argentina en el exterior, pues un sector optó por apoyar la recuperación del archipiélago. Cada uno de estos momentos generó nuevas campañas de solidaridad que utilizaron estos acontecimientos para denunciar a los respectivos regímenes militares inspirándose a su vez, en el plano artístico, para ilustrar de manera burlesca lo que en ese preciso momento estaba sucediendo.

El hecho de que Suecia tuviera una población mucho menor que la francesa, en esos años bastante más homogénea en términos étnicos dada la escasa presencia de refugiados de otros continentes, así como unas características culturales más distantes con Latinoamérica, hizo que la solidaridad con esta región, así como la presencia de exiliados fuera notablemente más visible que en Francia, país en el que ya estaban conviviendo numerosos colectivos de sus antiguos territorios coloniales o de sus provincias de ultramar. Además, las propias características culturales francesas eran bastante más cercanas a Latinoamérica que las suecas, de manera que su integración o adaptación en el paisaje urbano fue inmediato. Ello se refleja, por ejemplo, en la rápida y fácil conexión de la sociedad francesa con las causas latinoamericanas, sin necesidad de mediadores o interlocutores. En Suecia, a pesar del enorme compromiso, el desconocimiento general de la cultura latinoamericana de los primeros años favoreció que muchas de las obras fueran traducidas desde el español al sueco, tanto literarias como musicales (GRADSKOVA; QUIRICO, 2016, p. 53). Así, canciones de Víctor Jara o Violeta Parra fueron convertidas al sueco por artistas como Jan Hammarlund, Cornelis Vreeswijk ${ }^{23}$ o Arja Saijonmaa. Otros músicos suecos de renombre también se involucraron muy fuertemente en las actividades de solidaridad con Latinoamérica, especialmente Björn Afzelius (WESSLÉN, 2014) y Mikael Wiehe (WIEHE, 2010).

En el campo cultural, ciertos "mártires" se tornaron en íconos de la represión dictatorial del Cono Sur. Así, de Chile, junto a Salvador Allende y otros dirigentes

23 Este cantautor de los Países Bajos residente en Suecia también publicó un disco con canciones traducidas al neerlandés. 
políticos asesinados, el poeta Pablo Neruda y el cantautor Víctor Jara se convirtieron en figuras muy visibles de las actividades de solidaridad, especialmente de la mano de los militantes del PC chileno dado que ambos fueron militantes comunistas. El caso de Neruda fue especialmente recurrente tanto en Suecia como en Francia, ya que durante el gobierno de la Unidad Popular fue embajador de Chile en París, y en 1971 le fue concedido el Premio Nobel de Literatura, razón por la que viajó a Estocolmo y participó en varias ceremonias, entre las que se destacó una velada organizada por el Club de los Cronopios, donde se agrupaba la mayoría de los republicanos españoles. Así, tanto suecos como franceses tenían a Neruda muy presente y recordaban con afecto sus estancias en sus respectivos países, especialmente durante los años inmediatos al golpe de Estado. ${ }^{24}$

De Argentina se produjo un fenómeno similar con los escritores Rodolfo Walsh y Haroldo Conti, el guionista de historieta Héctor Oesterheld, el cineasta Raimundo Gleyzer, entre otros. La principal diferencia con el caso chileno es que estos artistas no fueron, por lo general, acompañados de figuras políticas porque ninguna víctima de la dictadura militar había tenido ni trascendencia ni el respaldo internacional suficiente. Los retratos y las obras de estas personalidades procedentes del mundo artístico e intelectual eran evocadas constantemente y, además, se multiplicaron las traducciones a otros idiomas. Asimismo, en las actividades de solidaridad se mostraban sus rostros en afiches, banderolas o boletines, cobrando un protagonismo particular en la campaña por los “100 artistas argentinos desaparecidos” que impulsó la Association International de Défense des Artistes victimes de la répression dans le monde (AIDA) ${ }^{25}$.

Algunas figuras destacadas del ámbito cultural que habían sido encarceladas, e incluso torturadas, se exiliaron en Europa una vez que recuperaron su libertad. En lo que respecta a Brasil, puede nombrarse al director de teatro Augusto Boal, quien, tras su liberación en 1971, se exilió en Argentina, para dirigirse en 1976 a Portugal y finalmente, dos años más tarde, a Francia, país desde donde abanderó múltiples

\footnotetext{
${ }^{24}$ Su fallecimiento consternó fuertemente a los representantes diplomáticos de Suecia y Francia en Santiago. Ambos embajadores participaron en el funeral y durante su celebración fueron entrevistados por los canales de televisión de sus respectivos países.

${ }^{25}$ Por ejemplo, en las actividades de información y solidaridad de AIDA por Argentina se proyectaba una película de Gleyzer traducida al francés (CRISTIÁ, 2021).
} 
acciones de solidaridad. Asimismo, el pianista argentino Miguel Ángel Estrella, preso en Montevideo entre 1978 y 1980, o el director de teatro chileno Óscar Castro ${ }^{26}$ y su teatro Aleph, actuaron como una suerte de embajadores culturales de la denuncia de las dictaduras en sus respectivos países. Cineastas -como Fernando Solanas ${ }^{27}-$ y numerosos artistas plásticos se exiliaron en Francia, entre ellos el chileno Guillermo Núñez en 1975 y el argentino Luis Felipe Noé en 1976. Núñez, por ejemplo, había sido sufrido la prisión tras censurarse una exposición de su obra. Un caso paradigmático fue también el de José Balmes, quien vivenció un doble exilio: durante la Guerra Civil española su familia se refugió en Chile y, tras el golpe de Estado en ese país, debió huir a Francia. Entre otros, los artistas uruguayos Jorge Errandonea y Lino Cabrera también se dirigieron a París después de haber estado refugiados en Argentina entre 1974 y 1977. En la capital francesa elaboraron la gráfica de numerosas acciones de solidaridad con América Latina (CRISTIÁ, 2019).

El movimiento de defensa de los derechos humanos y la democracia en América Latina que se desarrolló en Suecia estuvo compuesto, al igual que en el resto de los países, de numerosas actividades culturales. Una buena parte de los primeros suecos en participar en la solidaridad con esa región procedían de los comités de solidaridad con Vietnam, una causa que captó una gran adhesión en Suecia (KILANDER, 2007), de manera que inicialmente se siguieron pautas y estrategias muy similares.

A diferencia de países más atractivos para la intelectualidad, escritores y artistas latinoamericanos de renombre -tales como Francia, España o Italia- Suecia no fue destino preferente para refugiados de ese estrato social y profesional. A pesar de tener una política de refugio generosa, especialmente en los primeros años, llegaron fundamentalmente trabajadores industriales y militantes de organizaciones armadas. En no pocas ocasiones, debido a su escasa formación y desarrollo cultural, estas personas desconocían dónde se encontraba Suecia en el mapa, o incluso confundían el país, como

\footnotetext{
${ }^{26}$ Después de pasar dos años en campos de concentración chilenos, Óscar Castro y su hermana María Antonieta, fueron recibidos en París en 1976. Durante su cautiverio, la madre de ambos (Julieta Ramírez) y el marido de "Marieta" (John Mc Leod) fueron desaparecidos.

${ }^{27}$ Los primeros meses de exilio de Solanas trascurrieron en Madrid, antes de instalarse en 1977 en París, donde tenía redes profesionales que le permitieron insertarse laboralmente.
} 
aún suele pasar, con Suiza. ${ }^{28}$ Eso se tradujo en que, en buena medida, la producción artística producida por exiliados fue realizada inicialmente por aficionados, quienes a lo largo de su vida en Suecia fueron desarrollando sus capacidades y formación para finalmente convertirse, en varios casos, en reconocidos artistas. Desde los años treinta, con la llegada del Partido Socialdemócrata al poder, el Estado sueco comenzó a ofrecer generosas subvenciones en el plano de la educación popular, diseñando así programas gratuitos de los que pueden beneficiarse personas con bajos recursos. Además, dentro de esta línea, también ha existido un apoyo económico a asociaciones culturales civiles. Por estas razones, además de la gratuidad de la educación en todos los niveles, los refugiados pudieron adquirir amplios conocimientos, y, a su vez, desarrollar unas capacidades artísticas que habrían sido prácticamente imposibles en otros destinos. El arte en el sentido amplio se convirtió en una terapia para los exiliados que habían sufrido prisión política y tortura. Si en un primer momento, su creatividad se desarrolló en denunciar los crímenes de las respectivas dictaduras del Cono Sur, años más tarde, abordaron también otras temáticas. Fue así como numerosas personas que no tenían experiencia -o limitada- en el terreno artístico, una vez que llegaron a Suecia pudieron desarrollar sus capacidades. En no pocos casos, se trató de dramaturgos, músicos o pintores, que procedían de las organizaciones más radicales, tales como el Movimiento de Izquierda Revolucionaria (MIR) de Chile o Movimiento de Liberación NacionalTupamaros de Uruguay. Entre ellos, se podrían nombrar al uruguayo Pepe Viñoles, o los chilenos Berta Guerra, Sergio Infante, Igor Cantillana, Enrique Durán, Adrián Santini o Rolando Pérez, entre muchos otros.

\footnotetext{
${ }^{28}$ A diferencia de países del sur y del centro de Europa, los vínculos políticos y económicos de los países latinoamericanos con Suecia fue secundario. Del mismo modo, la región tampoco fue un destino preferente de los emigrantes suecos del siglo XIX y comienzos del XX, a diferencia de Estados Unidos. Para tener una visión completa de las relaciones entre Suecia y América Latina, véase: Karlsson; Magnusson \& Vidales (1992).
} 


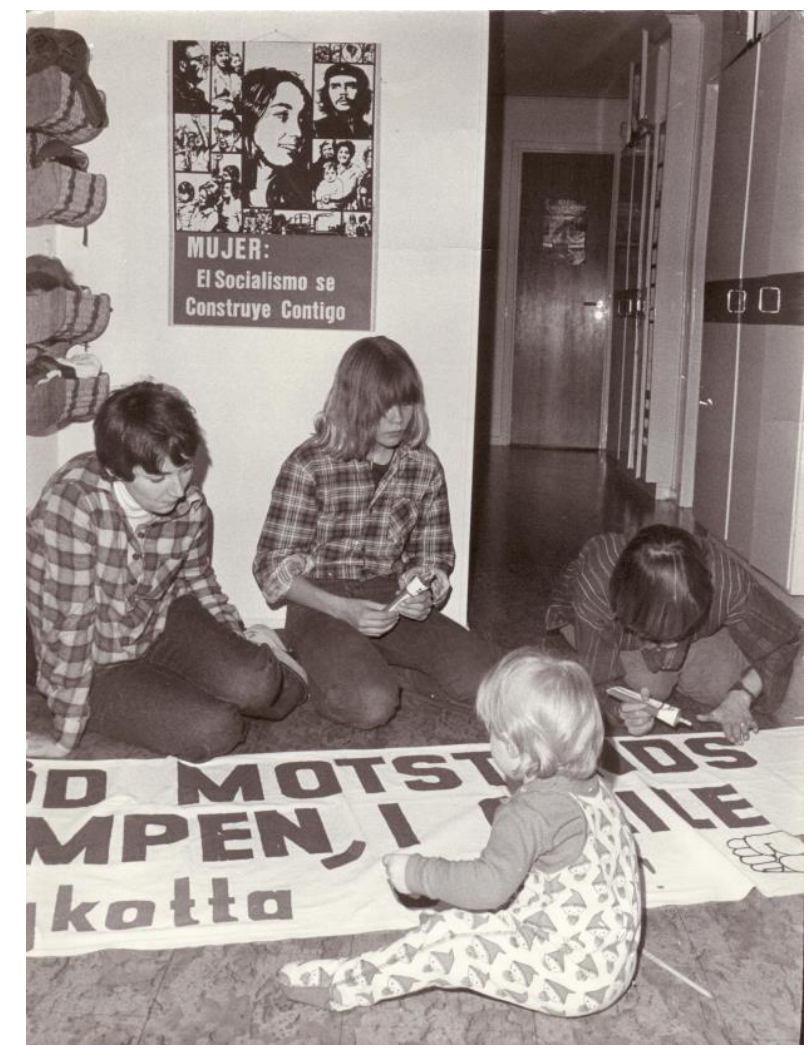

Fotografía no 3: Elaboración casera de una pancarta en solidaridad con Chile en Åkersberga (1976). Fuente: Colección privada de Göran Salnäs.

La producción cultural de la solidaridad y el exilio tuvo dos dimensiones distintas, si bien con elementos claramente cruzados. En las veladas y conciertos, por lo general, se buscaba la adhesión de la sociedad sueca y francesa a la denuncia de los regímenes dictatoriales, convocando la música de grandes artistas populares del momento como los grupos chilenos Inti Illimani y Quilapayún, o los argentinos Cuarteto Cedrón. También se apelaba a otros elementos populares latinoamericanos, como el arte precolombino, con motivos que en ocasiones no guardaban directamente relación con los acontecimientos políticos recientes, si bien es cierto que los espacios utilizados para ello solían estar decorados también de afiches que denunciaban los crímenes cometidos. Sin embargo, la producción cultural del exilio estuvo marcada por el dolor, la nostalgia, el duelo y el sentimiento de soledad. El Teatro Aleph en Francia compañía teatral chilena rearmada en Europa por su director Óscar Castro- recurrió a la 
temática del desarraigo del exilio ${ }^{29}$, apelando a la emoción del público en lo que la prensa llamó "una fiesta calurosa de solidaridad" ${ }^{30}$. En Suecia, el contraste paisajístico y cultural con los países del Cono Sur, en muchos casos, acentuó esos sentimientos, los cuales fueron claramente reflejados en las producciones de los exiliados. ${ }^{31}$

Un sector del colectivo de intelectuales que vivieron su exilio en Suecia se integró en el sistema educativo sueco, tanto a nivel de primaria, de secundaria como universitario. Con su incorporación en colegios, liceos y universidades, estos profesionales empezaron a compartir su conocimiento y vivencias sobre lo que estaba ocurriendo en sus países de origen. El Estado sueco ofreció facilidades para que los exiliados que formaban parte de los cuerpos docentes de las universidades de sus respectivos países pudieran seguir desarrollándose en ese ámbito (ÅKERLUND, 2016). De ese modo, desde el primer momento tras producirse el golpe de Estado en Chile, las universidades suecas contaron con especialistas latinoamericanos, inicialmente procedentes de las Ciencias Sociales y Económicas, y la Literatura. Más tarde, también se incorporaron de otras disciplinas, y, además, una parte de los exiliados obtuvieron becas para seguir con sus estudios en Suecia. Por este motivo, la producción académica relacionada con temáticas latinoamericanas aumentó significativamente en Suecia, las cuales prácticamente eran inexistentes hasta la fecha. ${ }^{32}$

La fuerte presencia de jóvenes intelectuales y artistas argentinos y chilenos en Francia permitió el florecimiento de una cultura de la resistencia, particularmente en el caso de estos últimos por la prolongación de su exilio. La acción militante, en continuidad a la desarrollada durante el gobierno de la Unidad Popular, adoptó una

\footnotetext{
${ }^{29}$ Su obra La increíble y triste historia del general Peñaloza y el exiliado Mateluna relata sensiblemente la experiencia en un lenguaje poético que incluía la simbólica valija del exiliado, siempre armada como expresión de la resistencia al destierro y de las obstinadas ansias del regreso.

${ }^{30}$ Gilles Sandier, «La troupe chilienne Aleph invitée à la Cartoucherie», Le Matin, 17/05/1980.

${ }^{31}$ La historiadora María Luján Leiva tiene un detallado trabajo sobre las principales temáticas de inspiración de los artistas y escritores latinoamericanos exiliados en Suecia (1996).

32 Hasta la llegada de los latinoamericanos, la única obra que denunciaba las condiciones políticas, sociales y económicas del continente había sido escrita por Lindqvist (1969). Por lo general, los trabajos de los autores latinoamericanos residentes en Suecia se centraron en aspectos políticos, sociales y económicos relacionados con los regímenes dictatoriales o los gobiernos predecesores. Una parte mayoritaria de esta producción procedió de los académicos del Instituto de Estudios Latinoamericanos de la Universidad de Estocolmo y del Instituto de Estudios Iberoamericanos de la Universidad de Gotemburgo. En las últimas dos décadas, también han empezado a realizarse algunos trabajos testimoniales de lo que fue la experiencia de solidaridad con Chile (CONTRERAS, 2003).
} 
multiplicidad de formas en esas tierras, donde se plegó a una vasta solidaridad. El capital simbólico y político del flujo de sectores con formación universitaria y artística dio como resultado la multiplicación de publicaciones, de reflexión intelectual y de producciones artísticas de diverso tipo, con una impronta colectiva y popular (PROGNON, 2008; MOINE, 2015).

En las manifestaciones, se combinaba la denuncia individual -el reclamo por un familiar, por ejemplo- con la colectiva, la de todos los desaparecidos de ese país o de América Latina. En los reclamos semanales frente a la embajada de argentina de París que se iniciaron en octubre de 1978 encabezados por el Club de droits socialistes de l’homme-, además de pañuelos blancos y cánticos contra la dictadura se exponían las fotografías de identidad de los desaparecidos franceses con su fecha de desaparición [ver fotografía 1]. En las presiones al gobierno francés para incidir este dato no es menor, particularmente porque el gobierno de Girard d'Estaing (1974-1981) aceptó la venta de armas a las dictaduras durante esos años. De manera recurrente, asistían a la concentración figuras reconocidas del Partido Socialista, así como intelectuales y artistas franceses solidarios. Además, los artistas plásticos uruguayos Lino Cabrera y Jorge Errandonea realizaron una larga bandera pintada con la representación de las madres de Plaza de Mayo, con la que éstas podían estar simbólicamente presentes en las calles de París en esa manifestación simultánea a las rondas que se realizaban en Buenos Aires (CRISTIÁ, 2019). 


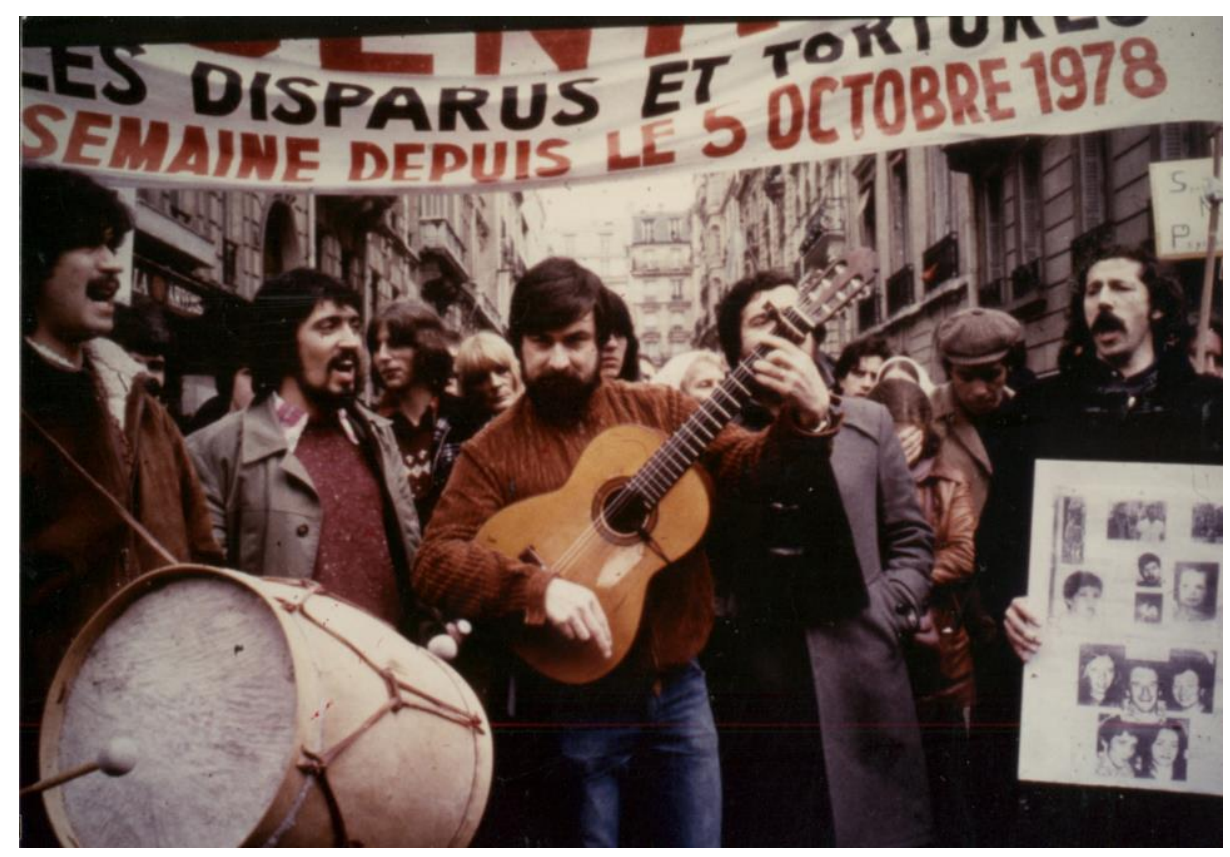

Fotografía nº 4: El grupo chileno Quilapayún tocando durante la manifestación organizada por el Club de droits socialistes de l'homme todos los jueves desde octubre de 1978 frente a la embajada argentina en París. Fuente: Colección Nouveaux Droits de l'Homme, Archivo General de la Memoria (Argentina).

Del mismo modo que los músicos realizaban giras de solidaridad por distintos países de Europa, se organizaron exposiciones itinerantes. Entre marzo y abril de 1978, el Museo de Arte Moderno de Estocolmo albergó una exposición temporal del "Museo Internacional de la Resistencia Salvador Allende" (LEBEAU, 2020; CAMACHO PADILLA, 2011, p. 102), y más tarde recorrió una veintena de localidades de Suecia. En 1981, se habilitó un espacio en la isla de Lidingö, cerca de Estocolmo, para albergar las obras donadas por artistas suecos, las cuales fueron transferidas a Santiago en 1991. También AIDA organizó una muestra de obras del pintor argentino desaparecido Remo Berardo que se presentó en varias ciudades francesas y en Suecia en 1982. Asimismo, una exposición colectiva solidaria por los "100 artistas argentinos desaparecidos", con obras donadas principalmente por artistas europeos, recorrió distintas ciudades de ese continente, vendiéndose algunas de las piezas para juntar fondos para los familiares de desaparecidos. También se realizaron 100 pinturas-banderas para utilizar en las marchas de AIDA por Argentina que se organizaron en diferentes ciudades, tras lo cual un grupo 
fue donado a Madres de Plaza de Mayo a fines de 1983. Así, una vez concretado el objetivo del retorno de la democracia en el país, la donación puede emparentarse a los proyectos de los museos de la solidaridad por Chile o Nicaragua (CRISTIA, 2021).

\section{Características de la cartelería de la solidaridad con Chile y Argentina}

Desde el primer momento, la producción gráfica fue una de las principales herramientas de denuncia de las violaciones a los derechos humanos que se estaban cometiendo en Latinoamérica. No se trató de un fenómeno exclusivo, pues la propaganda política venía haciendo uso de la imagen desde hacía décadas. Experiencias como la revolución rusa, la Guerra Civil española, los movimientos de liberación africanos y asiáticos, y la Guerra de Vietnam, entre muchos otros, habían sido ilustradas en afiches de todo tipo, colores y tamaños. En tanto el afiche político debe ser claro, directo y, además, captar la atención social con rapidez, es necesario utilizar el máximo de creatividad.

Una gran parte de la cartelería de la solidaridad con América Latina, y más concretamente con Chile y Argentina, realizada desde Suecia y Francia permanece anónima. Sin embargo, algunos artistas suecos de renombre participaron en la producción gráfica con Chile, ${ }^{33}$ como Christer Themptander, Kjartan Slettemark, Lars Hejll, Sture Johahesson y Ulf Rahmberg, entre otros, lo cual no ocurrió en el mismo nivel con el caso argentino, ya que el número de artistas suecos que se implicaron fue menor, destacándose esencialmente Bengt Hellgren, y también Christer Temptander. Respecto al anonimato que prevaleció tanto por Chile como Argentina, las razones fueron múltiples; además del posible descuido del artista a la hora incluir su nombre o la inexperiencia, o incluso la voluntad de que represente al colectivo que lo imaginó, el temor a ser identificado por los servicios de seguridad de las respectivas dictaduras fue en ocasiones la razón por la cual se prefirió operar en el anonimato o bien utilizar seudónimos.

\footnotetext{
${ }^{33}$ Algunos de estos afiches están disponibles en la obra de Angsätter (2013). 
En el discurso desarrollado por las organizaciones de solidaridad se identifica un pasaje progresivo de una preeminencia de consignas y una iconografía vinculada inicialmente a la revolución (como fusiles, puños y armas levantadas, el rostro del Che Guevara y/o de otros líderes guerrilleros) y más tarde a los derechos humanos (fotografías de desaparecidos y víctimas emblemáticas, la imagen de los dictadores, además de sangre y cadáveres, por ejemplo), cuyos elementos acompañan visualmente la transformación del discurso y de la argumentación empleada. Curiosamente se recurrió a la infancia en ambas esferas, donde en ocasiones el niño aparecía armado como un elemento central de la revolución, con una imagen de seguridad, determinación, pero en otras, como víctima de las injusticias y la pobreza. Este doble discurso se desarrolló sobre todo en la cartelería de la solidaridad con la revolución en Centroamérica en la segunda mitad de la década de los años setenta y a lo largo de los ochenta (RAMÍREZ PALACIO, 2018).

En ese segundo momento, la producción visual se centra en mostrar, develar, aquello que las dictaduras intentaban disimular o enmascarar, la violencia ejercida contra sus ciudadanos. Allí, la imagen cumple un rol fundamental en la denuncia, sensibilizando sobre la situación latinoamericana al hacer visible lo lejano y escondido. Así se intentaba permitir imaginar de alguna manera la represión, desandando lo que Didi-Huberman (2003) llamó la "maquinaria de la desimaginación"34 de esos regímenes.

En la gráfica de la solidaridad se incluyó a menudo fotografías de desaparecidos y de líderes revolucionarios o de figuras consagradas, tales como Salvador Allende, pero también hubo espacio para el humor y la ironía a la hora de representar a los dictadores. Probablemente el más representado haya sido Augusto Pinochet, y en particular la fotografía tomada por Chas Gerretsen en 1973 en la que aparece con los brazos cruzados y lentes oscuros, encarnando el rol de militar duro y opresivo, recreando de alguna manera un estereotipo de villano de historieta. Esta imagen sirvió para una multiplicación de mensajes visuales de denuncia, caricaturas, afiches, gráficas tanto en Francia (GÁRATE, 2015) como en Suecia. En lo que respecta a Argentina,

34 Este concepto es desarrollado por Didi-Huberman refiriéndose específicamente a los campos de concentración nazis. 
numerosas caricaturas se gestaron durante la campaña internacional de boicot al mundial de fútbol de 1978, en la que se ironizó especialmente sobre Jorge Rafael Videla. En ambos países europeos, tales como Francia o Suecia, se usó también material gráfico del artista Ricardo Carpani, ${ }^{35}$ en esos años exiliado en España.

Con relación a la producción gráfica realizada por los movimientos de solidaridad con las causas de América Latina, se identifica una significativa diversidad temática y artística ${ }^{36}$. Un motivo central fue la influencia de las propias corrientes artísticas europeas, pero también de otros países del mundo con comunidades de emigrantes significativas. Europa había tenido su propia experiencia de solidaridad con otras causas mundiales, generando también una significativa producción audiovisual. Así, diseñadores locales, pero también procedentes de otros continentes, se involucraron fuertemente con la denuncia de los atropellos que se cometían en el Cono Sur, utilizando para ello una gran creatividad. A modo de ejemplo, se podría destacar la participación de españoles en los primeros años, dado que el número de exiliados republicanos en Francia en esos momentos era aún muy alto, y aunque en Suecia no tan numeroso, sí era muy activo.

Así, la producción gráfica sobre Chile y Argentina producida en Suecia ${ }^{37}$ y Francia tuvo igualmente una gran diversidad temática. ${ }^{38}$ Entre las más recurrentes se encontró el uso de la bandera nacional y de sus colores, pero también se apeló a la bandera de los Estados Unidos, denunciado la injerencia de la Casa Blanca en la política interna de los países en los que se habían producido golpes de Estado. En los afiches, tal como se observa en los ejemplos expuestos, se hacían alusiones a distintos temas, tales como: figuras del mundo cultural, como Pablo Neruda [imagen 1]; retratos de los

\footnotetext{
${ }^{35}$ Según Joaquín L. Rosell: “[...] yo, en acuerdo con el artista argentino Carpani, coloreé, imprimí y distribuí [postales con sus dibujos] por el país [Suecia]." Entrevista con Joaquín L. Rosell, ilustrador hispano-argentino, por correo electrónico [13/6/2021].

${ }^{36}$ La producción gráfica cubana fue innovadora e influente en otros horizontes. Más allá de los diseños de promoción cinematográfica impulsados desde el Instituto Cubano del Arte y la Industria Cinematográfica (ICAIC), la cartelería producida desde la Organización de Solidaridad de los Pueblos de Asia, África y América Latina (OSPAAAL) circuló por todo el mundo. Entre otros, véase los trabajos de Tardy \& Tesnière (2016); Stermer (1970) y Viñuela \& Mendéndez (2017).

${ }^{37}$ En los fondos del archivo y la biblioteca del movimiento obrero de Suecia, así como del Museo de la Memoria y los Derechos Humanos de Chile, se guardan una cantidad importante de los afiches de la solidaridad con Chile.

${ }^{38}$ La cartelería del movimiento de solidaridad con América Latina en términos generales ha sido poco investigada. Una excepción se encuentra en el reciente trabajo de Pilatowsky Goñi y Cabranes (2020).
} 
dictadores [imagen 4]; eventos deportivos, como el partido de la Copa Davis celebrado en Båstad entre jugadores suecos y chilenos [imagen 2], o el mundial de Fútbol de 1978 [imagen 6]; y a torturados, presos políticos y desaparecidos [imagen 3, 5 \& 6]. Se observa, por lo tanto, que en la cartelería se podían combinar varios elementos. La imagen 1 fue uno de los primeros afiches realizados en Suecia tras el golpe militar, a final de septiembre o comienzos de octubre de 1973, para anunciar una velada poética como homenaje a Pablo Neruda en solidaridad con Chile, y estuvo organizada por centros culturales suecos en colaboración con el principal centro cultural de republicanos españoles, el Club de los Cronopios, observándose la ausencia de organizaciones chilenas ya que su número en el país era todavía reducido, y, además, no se habían fundado aún. El segundo afiche, de dos años más tarde, fue diseñado por el artista sueco Kjartan Slettemark para el Chilekommitté (el organismo de solidaridad con Chile integrado principalmente por suecos y algunos chilenos, mayoritariamente del MIR) para boicotear el partido de la Copa Davis que se iba a celebrar en Båstad ${ }^{39}$. El tercer afiche fue realizado por el Salvador Allendekommitté (organismo de solidaridad con Chile integrado por exiliados chilenos de los partidos que habían formado la Unidad Popular) para denunciar la política represiva en Chile, aludiendo a los presos políticos y los desaparecidos.

\footnotetext{
${ }^{39}$ Un detallado estudio sobre el cruce de discurso visual que tuvo lugar con ocasión del partido ha sido realizado por Macchiavello (2009). 
Afiches del movimiento de solidaridad con Chile en Suecia

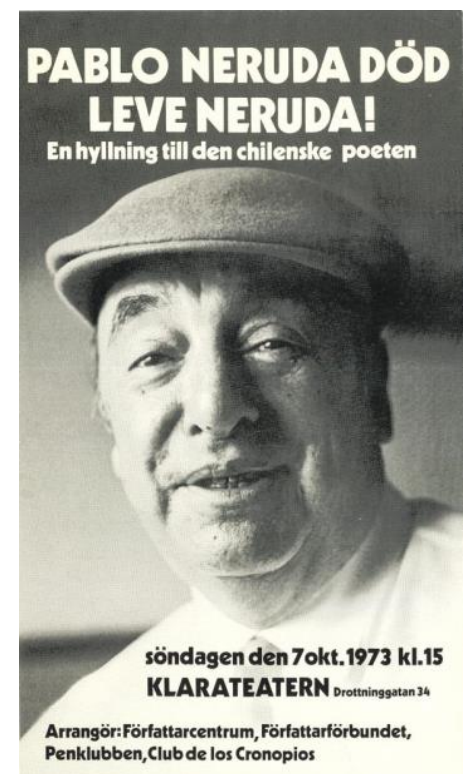

Imagen $n^{\circ} 1$ : Afiche "Pablo Neruda ha muerto. Viva Neruda". Varias organizaciones (1973). Autor:

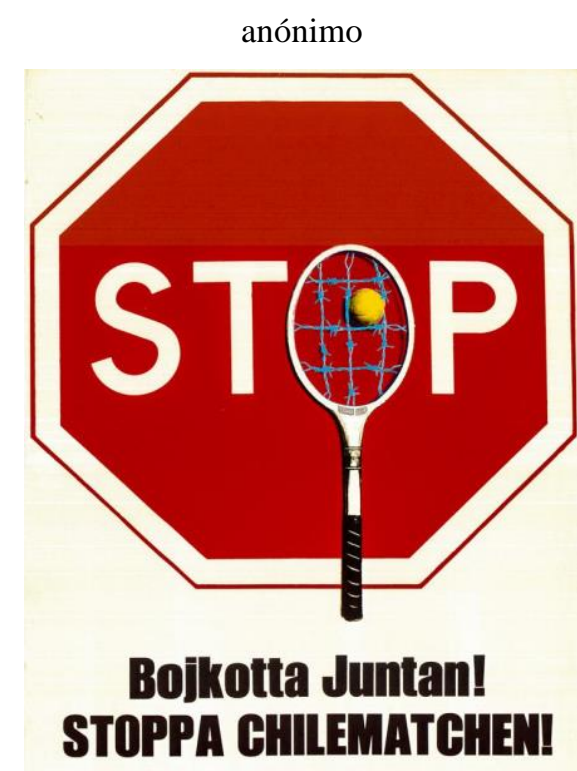

Imagen no 2: Afiche "Boicot a la junta. A parar el partido" Chilekommitté (1975). Autor: Kjartan Slettemark 


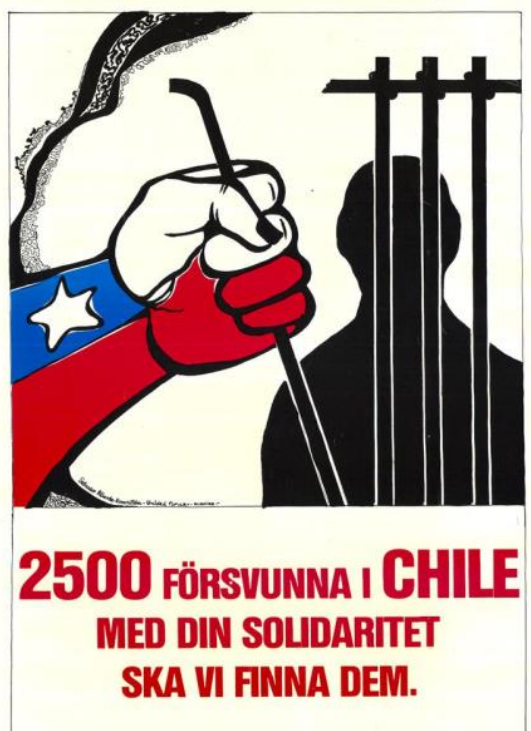

Imagen $n^{\circ} 3$. Afiche "2.500 desaparecidos en Chile. Con su solidaridad los vamos a encontrar" Salvador Allendekommitté (fecha sin determinar).

Autor: Germán Perotti.

Producción gráfica del movimiento de solidaridad con Argentina en Suecia

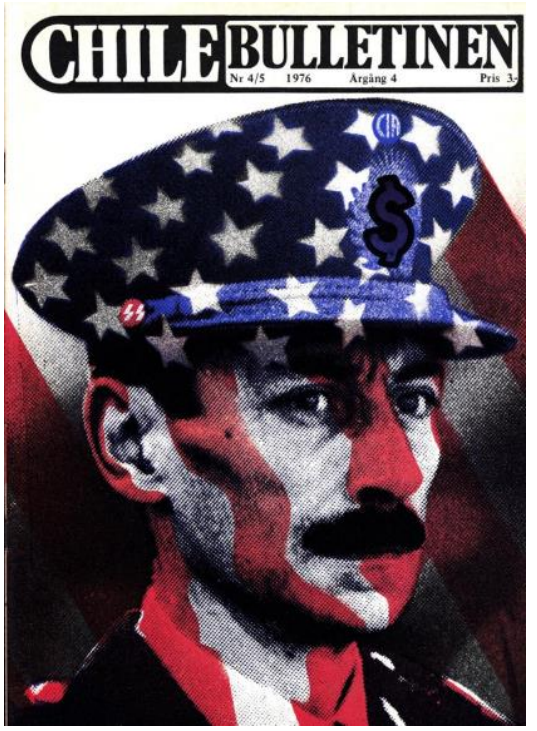

Imagen no 4: Portada del Chilebulletinen nº 4/5 (1976). Autor: Joaquín L. Rosell 


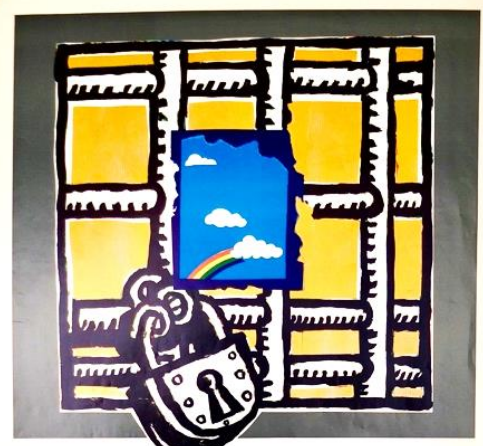

ARGITIIITA FRIHET ATT DE FÖRTRYGKTA

Imagen n 5: Afiche "Libertad para los oprimidos". KFUK-KFUM/ Argentinakommittén (1977).

Autor: Pepe Viñoles

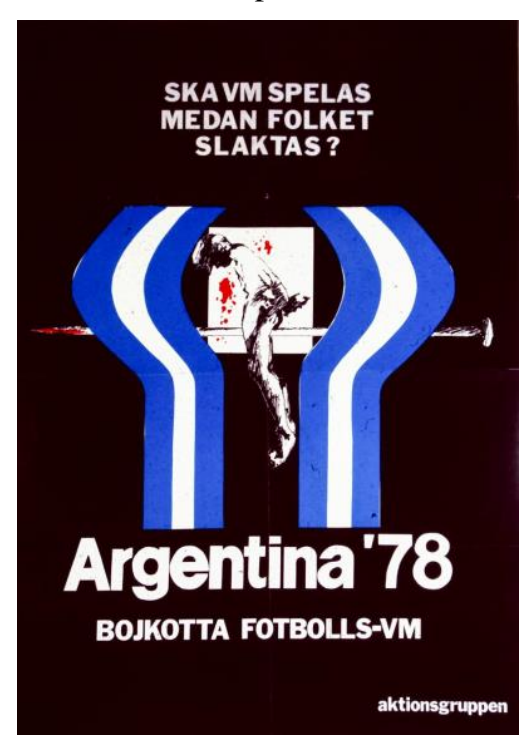

Imagen n ${ }^{\circ}$ 6: Afiche “¿Vamos a jugar mientras al pueblo lo carnean?” Aktionsgruppen (1978).

Autor: Pepe Viñoles

La solidaridad sueca con Chile se materializó en numerosos objetos, tales como libros, boletines, afiches, banderolas, postales, sellos, entre otros. En cambio, la solidaridad con Argentina fue mucho más limitada. Antes del golpe de Estado, en 1975, y con la llegada de exiliados a ese país, se fundó Argentinakommitté, siguiendo el modelo del Chilekommitté, perdurando hasta la primera mitad de 1980, curiosamente antes de finalizar la dictadura. Es posible que varios de sus integrantes más activos 
participaran en la operación retorno de Montoneros o acabaran dirigiéndose a otros países europeos con características culturales más similares a las argentinas.

Una diferencia primordial entre el Chilekommitté y el Argentinakommitté fue que el segundo estuvo integrado mayoritariamente por ciudadanos argentinos en colaboración con algunos suecos. Inicialmente usaron la sede central del Chilekommitté para preparar sus actividades de solidaridad y hacer uso de sus equipos gráficos, ${ }^{40}$ aunque poco después lograron tener su propio espacio. La producción de afiches fue considerablemente más limitada y no publicaron de manera regular boletines ni otros objetos. Las violaciones de derechos humanos por parte de la Junta Militar argentina fueron denunciadas también a través de las publicaciones del Chilekommitté, como su principal órgano de difusión, el Chilebulletinen, especialmente cuando tuvo lugar el golpe de Estado y con motivo de la celebración de la Copa Mundial de Fútbol en 1978. Asimismo, la mayor parte de las actividades organizadas en solidaridad con Argentina que tuvieron lugar fuera de Estocolmo, Uppsala, Lund y Gotemburgo, fueron organizadas por el Chilekommitté $e^{41} \mathrm{u}$ otros organismos de solidaridad en los que había una escasa representación argentina [fotografía 5], pues la solidaridad con Chile tuvo un gran alcance en todo el territorio nacional, lo que se tradujo en la existencia de más de 100 comités locales por todo el país.

Al igual que ocurrió en otros países europeos, se repudió las prácticas represivas haciendo uso de los símbolos nacionales argentinos, así como de los propios logotipos diseñados por el régimen militar para la ocasión. El dictador en ese momento, Jorge Rafael Videla, aparecía representado como un gaucho con la camiseta de la selección nacional jugando fútbol con un cráneo humano, supuestamente de una de las víctimas del terrorismo de Estado. Asimismo, en las calles de Suecia se colocaban televisores

\footnotetext{
${ }^{40}$ En el otoño de 1974, se creó el llamado Bildgruppen [el grupo de imagen] dentro del Chilekommitté con el fin de reunir toda clase de materiales visuales y de diseñar ilustraciones, tales como caricaturas, afiches, portadas y postales, entre muchos otros, destinadas al trabajo de solidaridad. Varios de los artistas que participaban en las tareas de solidaridad organizaron talleres para formar ilustradores. De ese modo, Joaquín L. Rosell ofreció un curso sobre cómo diseñar e imprimir afiches con serigrafía. Entrevista con Joaquín L. Rosell, ilustrador hispano-argentino, por correo electrónico [13/6/2021].

${ }^{41}$ A modo de ejemplo, Joaquín L. Rosell señala lo siguiente: "[El] Chilekommitté denunció [a la dictadura argentina] y gracias al gremio de trabajadores de puertos se impidió que desde la ciudad de Halmstad saliera un cargamento de munición $9 \mathrm{~mm}$. de fabricación sueca para la policía argentina. Pero lo despacharon después desde Hamburgo...”. Entrevista con Joaquín L. Rosell, ilustrador hispano-argentino, por correo electrónico [13/6/2021].
} 
criticando el espectáculo al evocar el número de presos políticos y desaparecidos, además del tipo de prácticas represivas utilizadas por la dictadura. Otros motivos recurrentes que denunciaban las consecuencias en el plano social y económico de la dictadura fueron imágenes de miseria, de desempleo, o de hambre, frecuentemente con rostros de niños desnutridos y mujeres desamparadas.

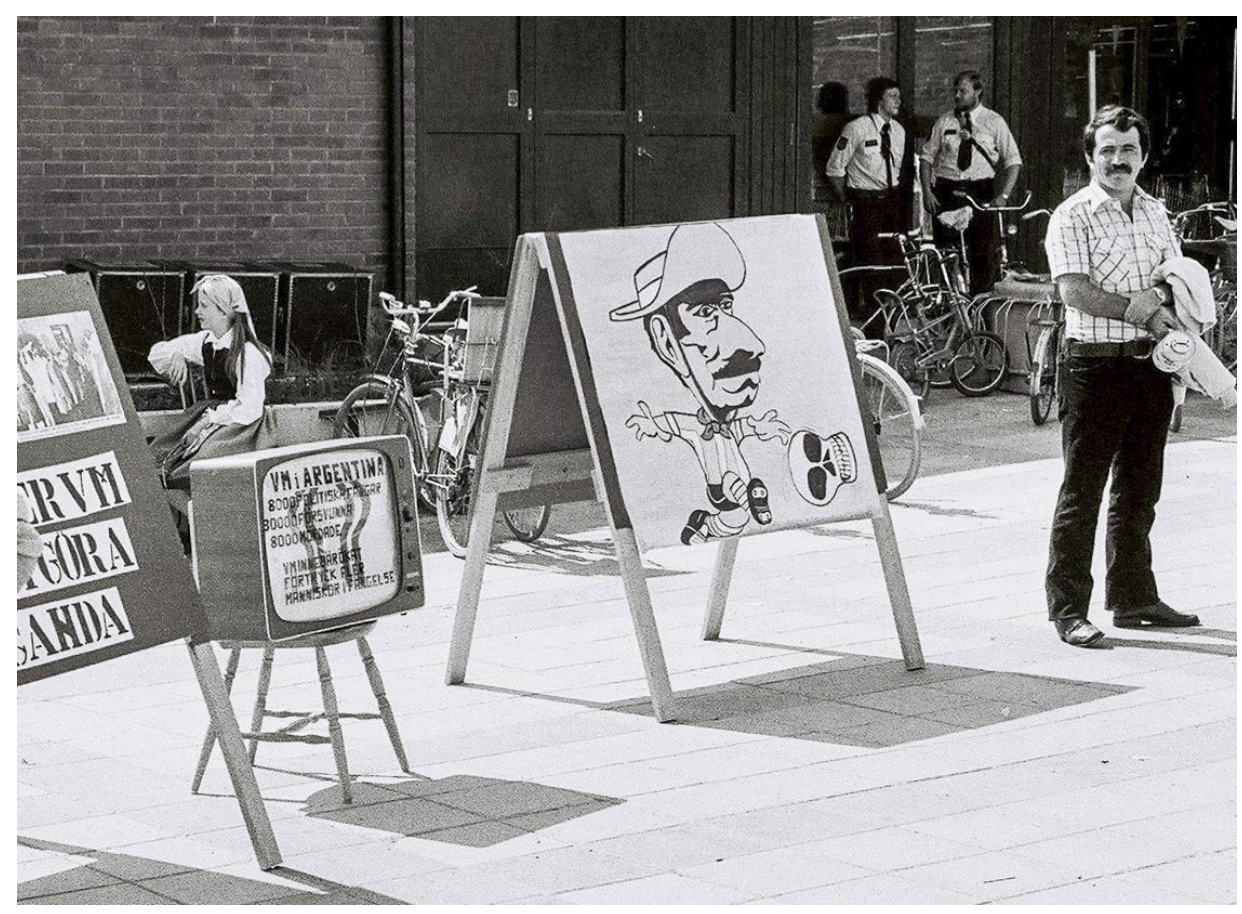

Fotografía no 5: Centro de Åkersberga (1978). Fuente: Colección privada de Göran Salnäs.

Entre los artistas y diseñadores que elaboraron los afiches en solidaridad con Argentina se encontraban exiliados latinoamericanos procedentes de otros países, como el uruguayo Pepe Viñoles, quien había trabajado estrechamente en la solidaridad con Chile y Uruguay, o exiliados argentinos como Liliana Blaustein. También argentinos llegados al país en los años sesenta, como Joaquín L. Rosell. Tanto Viñoles como Rosell formaban parte del Chilekommitté desde poco después de producirse el golpe de Estado de Pinochet. Sin embargo, no siempre es fácil reconocer la autoría de las ilustraciones ya que no siempre se firmaban las obras. Según Rosell:

Luego ocurre de que generalmente no solía firmar las obras, lo que hace que algunas cosas ni las recuerdo ni podían -ni pueden- identificarse a mi autoría. Por ejemplo, no son muchos los que sabían que era yo quien estaba 
detrás de toda una serie de postales, como la de Coca Cola. Yo había sacado la cuenta de que cada postal enviada [sería] vista por unas seis o diez o más personas, lo que no estaba nada mal. ${ }^{42}$

El nombre de Svante Grände, ciudadano sueco desaparecido en Tucumán en 1975 fue utilizado por el MIR para designar a su propio comité de solidaridad por un acuerdo establecido entre los propios exiliados argentinos y chilenos. Dado que Grände, antes de pasar a formar parte de las filas del Ejército Revolucionario del Pueblo (ERP), fue integrante del MIR, se optó por vincular su nombre a la experiencia chilena en lugar de la argentina. En el caso de Hagelin, si bien tuvo una gran visibilidad en los medios de comunicación, “el padre [...] nunca permitió que ninguna organización, ni política ni de solidaridad, ni argentina ni sueca, se inmiscuyera en las campañas por Dagmar. Todo lo manejó él, personalmente. Y de manera muy activa". ${ }^{43}$

En el caso de Francia, el compromiso y la profusión de imágenes fue importante para ambas experiencias latinoamericanas. Tempranamente se organizaron reuniones de solidaridad en el local del Centre d'études et d'initiatives de solidarité internationale (CEDETIM). Inicialmente llamado Centre socialiste de documentation et d'études sur les problèmes du tiers monde, el CEDETIM había sido creado en 1967 en el marco de las luchas de descolonización en Asia y África, ampliando una primera formación fundada dos años antes. Con cierta continuidad con la "cooperación roja" de quienes apoyaron la liberación argelina, el grupo inicial estaba compuesto por militantes combativos, principalmente del Parti Socialiste Unifié, que habían tenido experiencias profesionales y de cooperación en el Tercer Mundo, lo que les había permitido conocer otras realidades y mirar críticamente el comportamiento francés respecto de esas regiones (ZEROUALI, 2008).

En el CEDETIM, en el número 14 de la rue Nanteuil del distrito 15 de París, fue creado el Comité de Soutien à la lutte révolutionnaire du peuple chilien (Comité de Apoyo a la Lucha Revolucionaria del Pueblo Chileno) durante el verano europeo de 1972, extendiéndose en la creación de comités por toda Francia, y cobrando -después

\footnotetext{
${ }^{42}$ Entrevista con Joaquín L. Rosell, ilustrador hispano-argentino, por correo electrónico [13/6/2021].

${ }^{43}$ Entrevista con Enrique Ganuza, miembro fundador del Argentinakommitté, por correo electrónico [01/03/2021].
} 
del golpe de estado en Chile- gran incidencia en la denuncia internacional de la dictadura de Pinochet. El local fue pronto escenario del Comité de Soutien aux Luttes du Peuple Argentin (CSLPA), contando con militantes vinculados de alguna manera con Argentina que, reunidos desde fines de 1974, denunciaban la represión clandestina en ese país. Parte de sus integrantes había vivido en la región, como era el caso de François Gèze y Alain Labrousse, ya mencionados. Allí mismo surgieron los primeros debates de acciones de boicot al Mundial de Fútbol de 1978 y estrategias a seguir para denunciar la represión en Argentina, donde también circulaban militantes de distintas causas y exiliados de variadas nacionalidades en reuniones de comités de solidaridad que se sucedían en aquella sala. En la cartelería de ese primer período abundan los puños en alto, las bocas abiertas y la presencia de armas, así como la figura tutelar de Allende como bandera de la lucha [imágenes 6 y 7], mientras que en el boicot al Mundial de Fútbol ya se impuso un discurso visual anclado en la denuncia de la represión. 


\section{Afiches del movimiento de solidaridad con Argentina y Chile en}

\section{Francia}

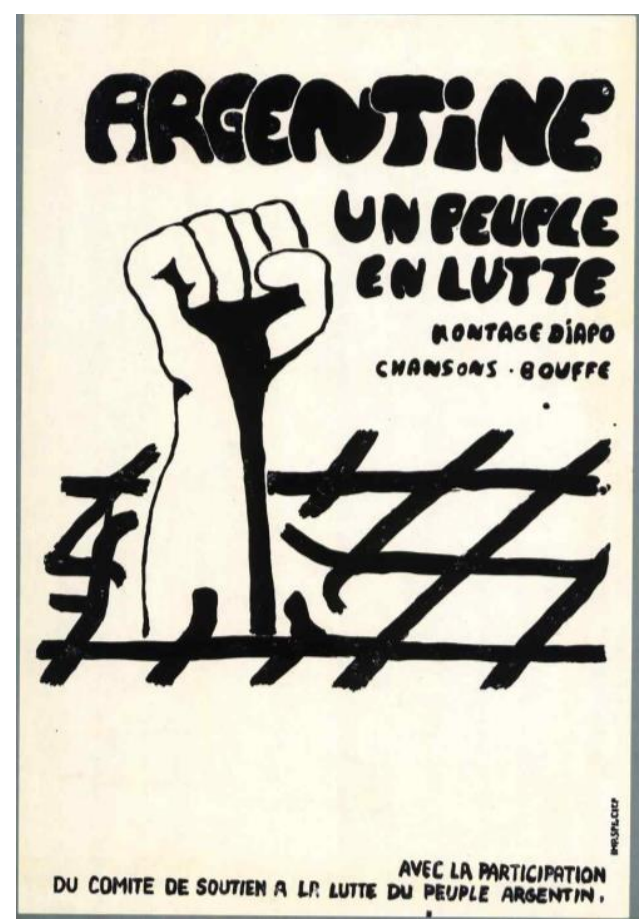

Imagen $\mathrm{n}^{\mathrm{o}}$ 7: Afiche convocando a una actividad de solidaridad con Argentina, CSLPA, circa 1976. Fuente:

Fondos de la Bibliothèque Pierre Monbeig (IHEAL).

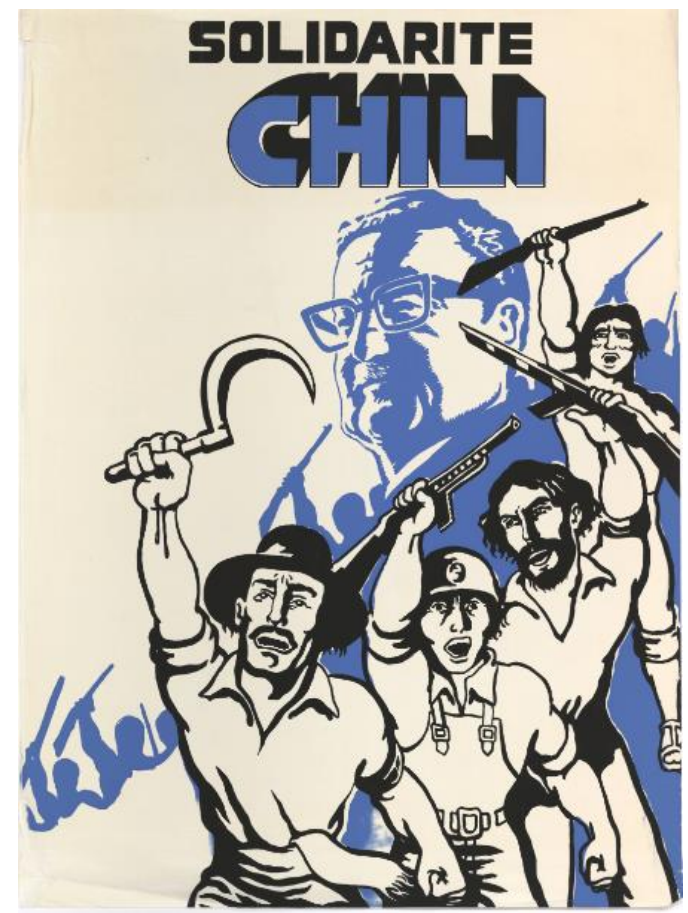

Imagen $n^{\circ} 8$ : Afiche de solidaridad con Chile. Fuente: Fondos de la Bibliothèque Pierre Monbeig (IHEAL) (DR).

En lo que respecta al boicot al mundial de fútbol de 1978, aunque la iniciativa de este movimiento de oposición fue probablemente sueca y adquirió diferentes características según los países, Francia suele ser considerado el epicentro del movimiento, en tanto fue allí donde cobró mayor impacto público (FRANCO, 2008). El surgimiento del Collectif pour le Boycott de l'Organisation par l'Argentine de la coupe du monde de football (COBA) en 1977 fue liderado por franceses, iniciándose con el núcleo de militantes del CSLPA, con una escasa presencia de argentinos. De manera similar a los argumentos mencionados, este movimiento internacional de repudio de la dictadura apeló a una iconografía que remitía al pasado traumático europeo, símbolos vinculados hasta entonces al nazismo, al fascismo y, en general, a la guerra. Sus campañas incluyeron una abundante confección de afiches, para lo cual requirieron de 
artistas y diseñadores, dando lugar también a piezas gráficas de edición limitada, como grabados y serigrafías. El repertorio de denuncia incluía esvásticas, águilas imperiales, cráneos, alambre de púas, armas, militares y sangre. Una de las consignas más recurrente de los materiales de difusión del COBA fue «pas de football entre les camps de concentration» («no al fútbol entre los campos de concentración»), la cual se graficaba en uno de los afiches que más circularon, transformando el logo oficial del evento deportivo hacia la denuncia. Así, las largas banderas que rodeaban la pelota de fútbol de aquel ícono se transfiguraban en los soportes de dos grandes alambres de púas. Era una clara referencia simbólica de los campos de concentración nazis, acompañada de una simbología contundente, no exenta de emotividad. Asimismo, la corriente proboicot también parangonaba este acontecimiento con los Juegos Olímpicos de Berlín de 1936, instrumentalizados por Hitler para ostentar la grandeza de su Nación. En la difusión del COBA se aludía de manera recurrente al oscuro pasado europeo, convocando a una actividad con la cita del dramaturgo y poeta alemán Bertolt Brecht «El que no sabe es un imbécil, pero el que sabe y calla es un criminal» ${ }^{44}$. Como parte de la campaña que reunió 100.000 firmas, se elaboró un disco que convocaba a movilizar a amplios sectores de las fuerzas progresistas francesas para evitar que dicho acontecimiento deportivo sirviera de apoyo al régimen dictatorial argentino. Articulando una amplia corriente crítica de más de 150 comités en Francia, el COBA declaraba que se comprometía a no descansar hasta que se liberaran a los presos políticos, se encontraran las personas desaparecidas y se restablecieran las libertades sindicales y políticas.

En definitiva, los comités de solidaridad de Francia, al igual que de Suecia, repudiaban cualquier acto que implicara un aval del gobierno francés a las dictaduras, ya fuera por relaciones económicas, diplomáticas, militares o deportivas. En las manifestaciones y en la gráfica se reiteraban consignas contra la complicidad del gobierno francés, mencionando tanto al presidente Georges Pompidou (1969-1974)

\footnotetext{
44 Afiche COBA «5 heures pour le boicot au Mundial»02/05/1978. Fondos de la Bibliothèque Pierre Monbeig (IHEAL).
} 
[imagen 11] como a Valéry Giscard d'Estaing (1974-1981) ${ }^{45}$ y otras que denunciaban la complicidad social como «Derrière la télé, écoutez les cris des torturés!» («iDetrás de la televisión, escuchen los gritos de los torturados!» $)^{46}$. En la gráfica, tanto sueca como francesa, se reiteraban los militares de rostros amenazantes y dientes filosos, la presencia de la sangre, de huesos y calaveras [fotografía 5, imágenes 5, 9, 10, 11, 12].

\section{Afiches del movimiento de solidaridad con Argentina en Francia}

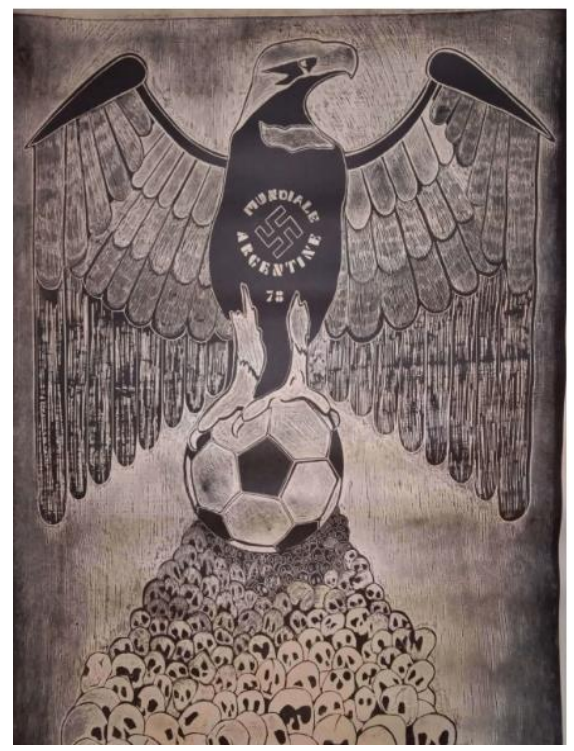

Imagen $n^{\circ}$ 9: Afiche de boicot al mundial de fútbol en Argentina del COBA, Francia, 1978. Fondo Liliana Andreone, Memoria Abierta.

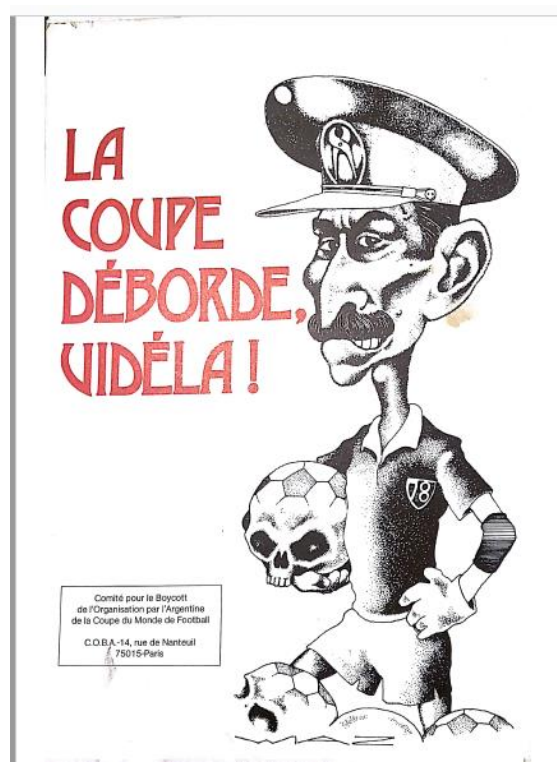

Imagen $\mathrm{n}^{\circ}$ 10: Folleto de boicot al mundial de fútbol en Argentina del COBA, Francia, 1978. Archivo personal de Liliana Andreone.

${ }^{45}$ El mensaje de este cartel era el siguiente: «Videla assassin, Giscard d'Estaing complice» («Videla asesino, Giscard d'Estaing cómplice»).

${ }^{46}$ Daniel Denis, «Aux chiottes l'arbitre», Supplément à Politique Aujourd'hui», 06/1978, disponible en: https://argonnaute.parisnanterre.fr/ark:/14707/a011403267955XicyeP/c8b62176a7 


\section{Afiches del movimiento de solidaridad con Chile en Francia}

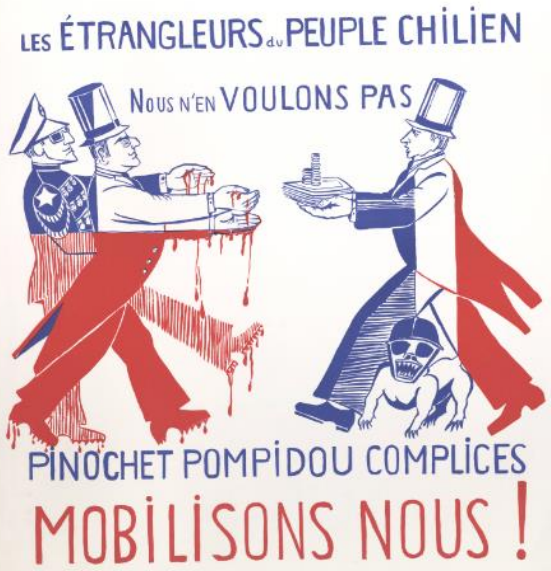

Imagen $n^{\circ} 11$ : "Les étrangleurs du peuple chilien, nous n'en voulons pas: Pinochet Pompidou complices mobilisons-nous !”.

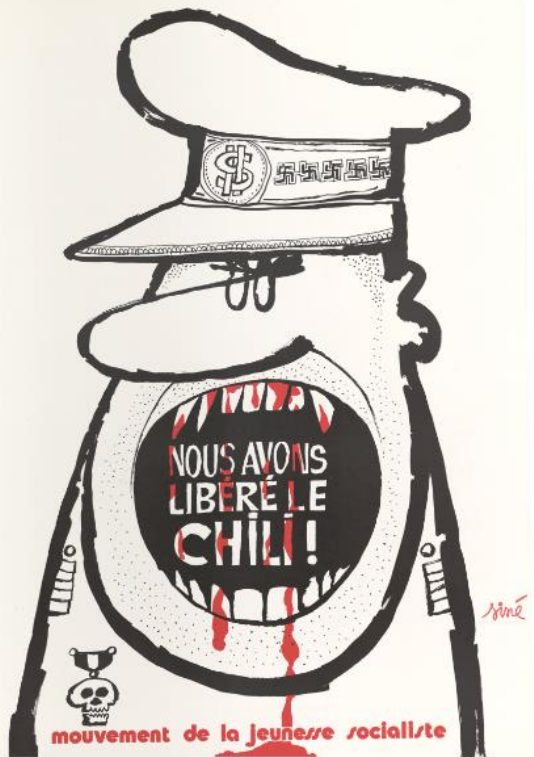

Imagen $n^{\circ}$ 12: Afiche del movimiento de la juventud socialista. Caricatura de Siné.

Fondos de la Bibliothèque Pierre Monbeig (IHEAL).

Fondos de la Bibliothèque Pierre Monbeig (IHEAL).

Si bien a finales de los años setenta el discurso visual revolucionario y las consignas de apoyo a la lucha armada se redirigieron a las experiencias de Nicaragua y de los focos guerrilleros en otros países centroamericanos, para ese momento esta iconografía gráfica se había abandonado de manera definitiva para las causas del Cono Sur. Estos casos aparecían vinculados ahora a los símbolos democráticos y a la defensa de los derechos humanos, valores que generaban más adhesión social, especialmente dentro de sectores políticos moderados. 


\section{A modo de conclusión}

Tanto Francia como Suecia fueron importantes países receptores del exilio chileno y argentino, y donde se gestó un significativo movimiento de solidaridad. En ambos casos se concentraron, asimismo, los principales grupos de exiliados chilenos en Europa. La comprometida recepción de refugiados y la colaboración con sus causas en ambos escenarios, se nutrió de los efectos de la politización de sus sociedades. Además de compartir una experiencia de compromiso en la Guerra Civil española -donde importantes filas de suecos y franceses participaron de las brigadas internacionales, resonando aún en sus sociedades-, los vientos progresistas de los sesenta soplaron de manera similar en ambos países. Si Francia fue epicentro de las movilizaciones de 1968, Suecia también vibró políticamente en ese marco de rebeldía juvenil, convirtiendo sus climas políticos en suelo fértil para la solidaridad con América Latina. Igualmente, desde finales de la década de los años cincuenta amplios sectores de esos países se habían implicado fuertemente en otras causas internacionales, en particular con los movimientos de liberación de diversos países de Asia y África, de manera que la efervescencia política conosureña ganó rápidamente la simpatía de las izquierdas francesas y suecas.

Sin embargo, ciertas particularidades nacionales dieron como resultado gestiones diferentes de esos procesos y de las dictaduras que les siguieron. En primer lugar, Francia y Suecia tenían distinta cercanía cultural con Latinoamérica, lo que facilitaba en el primer caso la adopción de esa causa, en tanto no solamente una proporción nada despreciable de la población entendía el español, sino que además la proximidad lingüística con el francés hallaba el camino a su comprensión. A pesar de su lejanía cultural, Suecia también había entablado vínculos especialmente con Chile durante el gobierno de la Unidad Popular, el cual había despertado un gran interés en sectores progresistas suecos que iban más allá de quienes simpatizaban por las estrategias revolucionarias guevaristas. A pesar de la distancia geográfica, entre 1970 y 1973, un par de decenas de jóvenes suecos viajaron a Chile para participar en distintas 
actividades de cooperación al desarrollo. Tras producirse el golpe de Estado, y una vez de regreso en Suecia, su mayoría se involucraron en el movimiento de solidaridad.

En segundo lugar, una diferencia sustancial la establecía los contrastes en las propias historias nacionales de esos países europeos, comenzando por la neutralidad de Suecia en la Segunda Guerra Mundial, mientras que Francia atravesó la ocupación nazi de su propio territorio, la deportación y muerte de decenas de miles de ciudadanos. Asimismo, en tanto Francia fue una potencia colonial, a diferencia de Suecia, protagonizó la Guerra de Independencia de Argelia y el efecto directo en su sociedad. Consecuencia de esas historias diferenciadas, la gráfica política y el discurso en el caso francés se volvió recurrentemente a referencias al nazismo, vinculando las víctimas latinoamericanas con las de la Shoa, y la complicidad de la pasividad/no intervención con la "colaboración", un tema altamente sensible para la ciudadanía francesa. Por su parte, Suecia, que no fue directamente afectada por ese proceso, tendió a relacionarlas más frecuentemente con otras causas internacionales y recurrió a sensibilizar a través de imágenes potentes y trágicas, como de personas víctimas de la represión o bombardeos, o en situación de pobreza o prisión política.

En tercer lugar, el perfil de los exiliados conosureños que llegaron a esos países fueron diferentes: mientras que en Francia se trataba de sectores más formados y de mayores recursos económicos, profundizando la tradicional preferencia de intelectuales y artistas, Suecia recibió mayormente una población de extracción popular o que había pertenecido a grupos armados, lo que se reflejó también en sus actividades culturales de denuncia y solidaridad. En este sentido, la producción realizada en Francia vino en muchos casos de personas de renombre que favorecieron su exhibición en espacios culturales de prestigio a los que no era fácil de acceder. Por esta misma razón, tuvo un mayor alcance regional, sobre todo en el continente europeo, que las obras o la cartelería producida en Suecia. Por último, debe insistirse en las diferencias entre los exilios argentino y chileno, en la temporalidad prolongada de estos últimos, y a la familiaridad y relación previa que existía entre su campo político con el europeo. En este sentido, si bien culturalmente Argentina puede considerarse como más próxima a Europa Occidental por la alta presencia de migrantes o descendientes de esta región, el 
mapa político chileno es más similar al de Europa Occidental, con partidos fácilmente identificables por sus similitudes ideológicas, sus nombres y sus planteamientos. Además, factores como la larga duración de la dictadura de Pinochet, así como una presencia superior del número de exiliados chilenos por encima de los argentinos en Europa, permitió que la causa chilena tuviera más visibilidad a nivel político y social, y, a su vez, los materiales diseñados y elaborados para sus campañas de solidaridad fueran más numerosos, logrando también un mayor alcance territorial.

En definitiva, la fuerte politización ideológica de finales de los años sesenta contribuyó a construir un ambiente favorable para la solidaridad tanto en Francia como en Suecia, dando continuidad a la militancia. En ese marco se buscó apelar a la sensibilidad y a la solidaridad de las sociedades europeas a través de diferentes estrategias, tendiendo progresivamente a abandonar la retórica e imaginería revolucionaria que promovía un sector importante de los exiliados por un discurso visual anclado en la denuncia de las violaciones de los derechos humanos y de afirmación de los valores democráticos.

\section{Referencias bibliográficas}

AGUIRRE ARGOMEDO, Estela; CHAMORRO MARTÍNEZ, Sonia. Memoria gráfica del exilio chileno 1973-1989. Santiago: Ocho Libro Ediciones, 2008.

ÅKERLUND, Andreas. Public Diplomacy and Academic Mobility in Sweden. The Swedish Institute and Scholarship Programs for Foreign Academics, 1938-2010. Lund: Nordic Academic Press.

ALDRIGHI, Clara; WAKSMAN, Guillermo. Tupamaros exiliados en el Chile de Allende 1970-1973. Montevideo: Ediciones Trilce, 2015.

AMADO, Ana. La imagen Justa. Cine argentino y política (1980-2007). Buenos Aires. Ediciones Colihue, 2009.

AMARAL DE AGUILAR, Carolina; CREPALDI CARVALHO, Danielle; RAMOS MONTEIRO, Lúcia; ADAMATTI, Margarida Maria; VILLAÇA, Mariana. Cinema: estética, política e dimensões da memória. Porto Alegre: Editora Sulina, 2019. 
AMIGO CERISOLA, Roberto; GUTIÉRREZ CASTAÑEDA, David, et al. (eds.). Perder la forma humana. Una imagen sísmica de los años ochenta en América Latina. Madrid: Museo Nacional Centro de Arte Reina Sofía, 2012.

ANGSÄTER, Håkan. Afficherna. Från den Svenska alternativrörelsen. 1967-1979. Bromma: Ordalaget Bokförlag, 2013.

BILDT, Lars. Om chilenare. Stockholm: Statens invandraverk, 1988.

BOLCHINSKY PINSÓN, Maylén. Dictadura, Fútbol y Patria. Juventud y experiencias juveniles, Argentina 1978. Pasado Abierto. Revista del CEHis, Mar del Plata, n. 7, p. 97-188, 2018.

CABALUZ, Fabian; AREYUNA-IBARRA, Beatriz. La ruta de Paulo Freire en Chile (1964-1969): alfabetización popular e influencias del marxismo heterodoxo. Revista Colombiana de Educación, v. 1, n. 80, 2020.

CAMACHO PADILLA, Fernando \& ASUNCIÓN CRIADO, Ana de la. El papel de Suecia en la Guerra Civil española (1936-1939). Les Cahiers de Framespa, $\mathrm{n}^{\circ} 27$, Toulouse, 2018.

CAMACHO PADILLA, Fernando. Los asilados de las Embajadas de Europa Occidental en Chile tras el golpe militar y sus consecuencias diplomáticas: El caso de Suecia. European Review of Latin American and Caribbean Studies, n. 81, p. 21-41, 2006.

CAMACHO PADILLA, Fernando. Suecia por Chile. Una historia visual del exilio y la solidaridad, 1970-1990. Santiago: LOM Ediciones, 2009.

CAMACHO PADILLA, Fernando. Una vida para Chile. La solidaridad y la comunidad chilena en Suecia 1970-2010. Santiago: LOM Ediciones, 2011.

CAMACHO PADILLA, Fernando; RAMÍREZ PALACIO, Laura. Fotografía y memoria visual de la dictadura militar. Reflexiones desde la historia. Revista Austral de Ciencias Sociales, Valdivia, n. 34, p. 53-70, 2018.

CAMPO, Javier; DODARO, Christian (comp). Cine documental, memoria y derechos humanos. Buenos Aires: Ediciones del movimiento / Nuestra América, 2007. 
CANELO, Brenda, Cuando el exilio fue confinamiento: argentinos en Suecia. In: Yankelevich, Pablo y Jensen, Silvina (comps.). Exilios. Destinos y experiencias bajo la dictadura militar. Buenos Aires: Libros del Zorzal, 2007, p. 104-107.

CARVAJAL, Fernanda: VARAS, Paulina; VINDEL, Jaime (eds.) Archivo CADA. Astucia práctica y potencias de lo común. Santiago: Ocho Libros Ediciones, 2019.

CASALS, Marcelo. Estado, contrarrevolución y autoritarismo en la trayectoria política de la clase media profesional chilena. De la oposición a la Unidad Popular al fin de los Colegios Profesionales (1970-1981), Izquierdas, número especial 44, p. 91-113, 2018.

CASTILLO ESPINOZA, Eduardo. Puño y letras. Movimiento social y comunicación gráfica en Chile. Santiago: Ocho Libros Ediciones, 2010.

CASTILLO TRONCOSO, Alberto del. Fotografía y Memoria. Conversaciones con Eduardo Longoni. Buenos Aires: Fondo de Cultura Económica, 2017.

CATOGGIO, Soledad: FELD, Claudia. Narrativas memoriales y reclamos diplomáticos a la dictadura militar: Francia y Estados Unidos frente al caso de las monjas francesas desaparecidas en Argentina (diciembre 1977 - noviembre 1978). Pasado y Memoria. Revista de Historia Contemporánea, n. 20, p. 141-170, 2020.

COMISIÓN NACIONAL DE REPARACIÓN Y RECONCILIACIÓN. Informe de la Comisión Nacional de Reparación y Reconciliación. Santiago: Andros Impresores, 1996.

COMISIÓN NACIONAL SOBRE LA DESAPARICIÓN DE PERSONAS. Informe de la Comisión Nacional sobre la Desaparición de Personas Nunca Más. Buenos Aires: Editorial Universitaria de Buenos Aires, 1984.

CONTRERAS, Francisco (ed.). 11 september - 30 år sedan statskuppen i Chile. Linköping: Bokförlaget Nixon, 2003.

CRISTI, Nicole; MANZI, Javiera. Resistencia gráfica. Dictadura en Chile. APJ Tallersol. Santiago: LOM Ediciones, 2016.

CRISTIÁ, Moira. AIDA. Una historia de solidaridad artística transnacional (19791985). Buenos Aires: Ediciones Imago Mundi, 2021.

CRISTIÁ, Moira. El drama argentino en una capital de los Derechos Humanos. Articulaciones de asociaciones, repudio y acciones de denuncia en escenarios parisinos 
(1977-1983). Revista de la Red Intercátedras de Historia de América Latina Contemporánea, v. 6, n. 10, 2019.

DENIS, Daniel. «Aux chiottes l'arbitre», Supplément à Politique Aujourd'hui», 06/1978, disponible en: https://argonnaute.parisnanterre.fr/ark:/14707/a011403267955XicyeP/c8b62176a7

DIDI-HUBERMAN, Georges. Images malgré tout. Paris: Éditions de Minuit, 2003.

DOOM, Elsa. El exilio argentino en Suecia (1973-1983), Jornadas de trabajo sobre exilios políticos del Cono Sur en el siglo XX, La Plata, 2012, disponible en: http://jornadasexilios.fahce.unlp.edu.ar.

DUPONT, Alexandre; MOINE, Caroline. Médiatiser la solidarité internationale: informer, mobiliser et agir au-delà des frontières. Le Temps des Médias, v. 2, n. 33, p. 6-19, 2019.

DUTRÉNIT BIELOUS, Silvia (coord.). El Uruguay del exilio: gente, circunstancias, escenarios. Montevideo: Ediciones Trilce, 2006.

ERRÁZURIZ, Luis Herán; LEIVA QUIJADA, Gonzalo. El golpe estético. Dictadura militar en Chile 1973-1989. Santiago: Ocho Libros Ediciones, 2012.

FRANCO, Marina. El exilio, argentinos en Francia durante la dictadura. Buenos Aires: Siglo XXI Editores, 2008.

FREIRE, Paulo. La educación como práctica de la libertad. Madrid: Siglo XXI.

GAILLARD, Anne-Marie. Exils et retours. Les itinéraires chiliens. Paris: L'Harmattan, 1997.

GÁRATE CHATEAU, Manuel. El nacimiento de un monstruo. El Golpe de Estado en Chile y la imagen de Augusto Pinochet a través de las caricaturas de la prensa escrita francesa (1973-1990). Caravelle, n. 104, p. 87-114. 2015

GARCÍA GUTIÉRREZ, Cristina Luz. Españoles en el infierno: españoles detenidos, desaparecidos y ejecutados en las dictaduras de Chile y Argentina. Tesis doctoral. Madrid: Universidad Autónoma de Madrid, 2013.

GÈZE, François; LABROUSSE, Alain. Argentine: révolution et contre-révolutions. Paris: Seuil, 1975. 
GILMAN, Claudia. Entre la pluma y el fusil. Debates y dilemas del escritor revolucionario en América Latina. Buenos Aires: Siglo XXI, 2003.

GRADSKOVA, Yulia; QUIRICO, Monica (red.). Solidariteten med Chile 1973-1989. Stockholm: Södertörn högskola, 2016.

HAGELIN, Ragnar. Mi hija Dagmar. Buenos Aires: Editorial Sudamericana, 1984.

HALL, Stuart. Vida y momentos de la primera Nueva Izquierda. New Left Review, n. 61, p. 163-182, 2010.

HORVITZ, María Eugenia; PEÑALOZA, Carla. Exiliados, desterrados del Cono Sur de América 1970-1990. Santiago de Chile: Erdonsain Ediciones, 2016.

JAGARE, Karl. Érase una vez... 1971-1972. Santiago: Fundación Salvador Allende, 2009.

JAMMET-ARIAS, Nathalie, Chile-Francia: los caminos del exilio (1973-1994). Revista de la Red de Intercátedras de Historia de América Latina Contemporánea, Córdoba, v. 7, n. 13, dic. 2020-mayo 2021.

JELIN, Elizabeth; LONGONI, Ana. Escrituras, imágenes y escenarios ante la represión. Buenos Aires: Siglo XXI editores, 2005.

JENSEN, Silvina. Los exiliados. La lucha por los derechos humanos durante la dictadura. Buenos Aires: Sudamericana, 2009.

KARLSSON, Weine; MAGNUSSON, ÅKE; VIDALES, Carlos. Suecia-Latinoamérica. Relaciones y Cooperación. Estocolmo: Instituto de Estudios Latinoamericanos de la Universidad de Estocolmo, 1992.

KIEVID, Jan de. "Posters of the Dutch Solidarity Movement with Chile (1972-1990)", European Review of Latin American and Caribbean Studies, n. 95, p. 109-113, 2013.

KIEVID, Jan de; EPPELIN UGARTE, Pablo; SNOEP, Karin. 40 años, 40 historias. Exiliados chilenos y solidaridad en Holanda. Santiago de Chile: LOM Ediciones / Dibam / Centro de Investigaciones Diego Barros Arana, 2015.

KILANDER, Åke. Vietnam var nära. En berättelse om FNL-rörelsen och solidaritetsarbetet i Sverige 1965-1975. Stockholm: Leopard Förlag, 2007. 
LEBEAU, Elodie. El Museo de la Solidaridad de la Unidad Popular al exilio (19711991). Una experiencia transnacional en tiempo de guerra fría cultural. Secuencia. Revista de Historia y Ciencias Sociales, México, n. 108, 2020.

LEFEBVRE-PEÑA, Michel. Guerra Gráfica. Fotógrafos, artistas y escritores en Guerra. Barcelona: Lunwerg Editores, 2013.

LEIVA QUIJADA; Gonzalo. Multitudes en Sombras. AFI. Santiago: Ocho Libro Ediciones, 2008.

LUGSCHITZ, Renée. Collègues, égales et camarades. Les volontaires étrangères dans la guerre civile espagnole (1936-1939), Cahiers d'histoire. Revue d'histoire critique, n. 141, 2019, p. 19-36.

LUJÁN LEIVA, María. Latinoamericanos en Suecia. Una historia narrada por artistas y escritores. Uppsala: Centro de Estudios Multiétnicos / Universidad de Uppsala, 1996.

MACCHIAVELLO, Carla. A parar el match: política, deporte y arte. Revista de Estudios Visuales, n. 32, p. 146-157, 2009.

MOINE, Caroline. 'Votre combat est le nôtre'. Les mouvements de solidarité internationale avec le Chili dans l'Europe de la Guerre froide. Monde(s), v. 2, n. 8, p. 83-104, 2015.

MORADIELLOS, Enrique. El reñidero de Europa. Las dimensiones internacionales de la guerra civil española. Barcelona: Ediciones Península, 2001.

MORALES MUÑOZ, Daniela. El exilio brasileño en México durante la dictadura militar, 1964-1979. México: Secretaría de Relaciones Exteriores, Dirección General del Acervo Histórico Diplomático, 2018.

MUSEO DE LA MEMORIA Y LOS DERECHOS HUMANOS. Archivo audiovisual. Colección del Museo de la Memoria y los Derechos Humanos. Santiago: Ocho Libro Ediciones, 2015.

MUSEO DE LA MEMORIA Y LOS DERECHOS HUMANOS. Dibujos en Prisión. Colección del Museo de la Memoria y los Derechos Humanos. Santiago: Ocho Libros Ediciones, 2014.

NORAMBUENA, Carmen. El exilio chileno: río profundo de la cultura iberoamericana. Sociohistórica, n. 23/24, primer y segundo semestre, p. 163-195, 2008. 
PATTIEU, Sylvain. Le « camarade » Pablo, la IVe Internationale, et la guerre d'Algérie. Revue historique, v. 3, n. 619, p. 695-729, 2001.

PEINADO, Quique. Futbolistas de izquierdas: Entre fútbol y política. Madrid: Léeme libros, 2013.

PILATOWSKY GOÑI, Priscila; CABRANES, Amaia. Militancias gráficas: carteles y solidaridad transnacional entre Francia y América Latina 1970-1980. Secuencia, México, n. 108, 2020.

POZO, José del (ed.). Exiliados, emigrados y retornados: chilenos en América y Europa, 1973-2004. Santiago: RIL ediciones, 2006.

PROGNON, Nicolas. La culture chilienne en France, une forme de résistance à la junte (1973-1994), Pandora: revue d'études hispaniques, n. 8, p. 205-220, 2008.

PROGNON, Nicolas. Les exilés chiliens en France, entre exil et retour (1973-1994). Latvia: Editions universitaires européennes, 2011.

RAMÍREZ PALACIO, Laura. Consensos transatlánticos. El niño combatiente en las imágenes de las guerrillas salvadoreñas que circularon por Europa. Revista de Estudios Globales y Arte Contemporáneo, Barcelona, v. 5, n. 1, p. 275-304, 2018.

REIN, Raanan. Solidaridad internacional y protestas transnacionales contra la Copa Mundial de Fútbol, Cuadernos de Aletheia, n. 3, marzo 2019.

RICHARD, Nelly. Fracturas de la memoria. Arte y pensamiento crítico. Buenos Aires: Siglo XXI, 2007.

RICHARD, Nelly. Poéticas de la disidencia: Paz Errázuriz - Lotty Rosenfeld. Barcelona: Ediciones Polígrofa, 2015.

RIOUX, Jean-Pierre; SIRINELLI, Jean-François (dir.) La guerre d'Algérie et les intellectuels français. Paris: Ed. Complexe, 1992.

RISLER, Julia. La acción psicológica. Dictadura, inteligencia y gobierno de las emociones 1955-1981. Buenos Aires: Tinta Limón, 2018.

ROJAS MIRA, Claudia Fedora. Las moradas del exilio: la casa de Chile en México (1973 - 1993). México: Universidad Nacional Autónoma de México, 2019. 
ROJAS MIRA, Claudia; SANTONI, Alessandro. Geografía política del exilio chileno. Los diferentes rostros de la solidaridad, Perfiles latinoamericanos, v. 21, n. 41, p. 123 $142,2013$.

RONIGER, Luis; SZNAJDER, Mario. La política del destierro y el exilio en América Latina. México: Fondo de Cultura Económica, 2013.

SÁENZ CARRETE, Erasmo. El exilio brasileño en Chile, Francia y México: la teoría de la dependencia. II Jornadas de Trabajo sobre Exilios Políticos del Cono Sur en el siglo XX. Montevideo: Universidad de La República, 2014.

SÁENZ CARRETE, Erasmo. El exilio latinoamericano en Francia: 1964-1979, México: UNAM/Unidad Iztapalapa-Potrerillos Editores, 1995.

SALGADO, Sebastião. Memorias. Desde mi tierra a la Tierra. Madrid: La Fábrica, 2014.

SALTI, Rasha; KHOURI, Kristine (ed.). Pasado inquieto: narrativas y fantasmas. Barcelona: MACBA, 2015.

SKOUTELSKY, Rémy. L'espoir guidait leurs pas : Les volontaires français dans les Brigades internationales, 1936-1939. Paris: Grasset, 1998.

STERMER, Dugald. The Art of Revolution, Castro's Cuba 1959-1970. New York: McGraw Hill, 1970.

STITES MOR, Jessica. Transition Cinema. Political Filmmaking and the Argentine Left since 1968. Pittsburgh: University of Pittsburgh Press, 2012.

STITES MOR, Jessica; SUESCUN POZAS, María del Carmen. The Art of Solidarity. Visual and performative politics in Cold War Latin America. Austin: University of Texas Press, 2018.

STJERNØ, Steinar. Solidarity in Europe. The history of an idea. Cambridge: Cambridge University Press, 2005.

STOBINSKI, Peter; GITTIS, Catherine; RÜCKERT, Bernd. 223 afiches de solidaridad con Chile. Berlín: Comité de Solidaridad de la República Democrática Alemana, 1981.

TARDY, Cécile; TESNIÈRE, Valérie. Internationales Graphiques [Catálogo de exposición], París: BDIC, 2016, 
VICO, Mauricio (ed.). El afiche político en Chile 1970-2013. Santiago de Chile: Ocho Libros Ediciones / Centro de Investigaciones Barros Arana, 2013.

VICO, Mauricio; OSSES, Mario. Un grito en la pared. Psicodelia, compromiso político, y exilio en el cartel chileno. Santiago: Ocho libros editores / Centro de Investigaciones Barros Arana, 2009.

VILLOTA RUIZ, Alejandro de (ed.). Líneas de la NO libertad. México: Universidad Nacional Autónoma de México, 2015.

VIÑUELA, Damian; MENÉNDEZ, José A. El cartel de la Revolución. Carteles cubanos entre 1959 y 1989. La Habana: Ediciones Polymita, 2017.

WESSLÉN, Gunnar. Björn Afzelius. En god man (och bara människa). Stockholm: Norstedts, 2014.

WIEHE, Mikael. Aldrig bli som ni. Sånger och synvinklarav. Stockholm: Ordfront Förlag, 2010.

YANKELEVICH, Pablo. Ráfagas de un exilio. Argentinos en México, 1974-1983. México: Fondo de Cultura Económica / El Colegio de México, 2011.

ZEROUALI, Abderrahim. Le CEDETIM, de la 'coopération rouge' à l'altermondialisme. In: ARTIÈRES, Philippe; ZANCARINI-FOURNEL, Michelle (dir.). 68. Une histoire collective (1962-1981). París: La Découverte, 2008, p. 559-565.

\section{Entrevistas}

Joaquín L. Rossel (Suecia)

Enrique Ganuza (Suecia) 